\title{
MR fluoroscopy in vascular and cardiac interventions (review)
}

\author{
Maythem Saeed $\cdot$ Steve W. Hetts $\cdot$ Joey English • \\ Mark Wilson
}

Received: 1 September 2010/Accepted: 13 December 2010/Published online: 26 February 2011

(C) The Author(s) 2011. This article is published with open access at Springerlink.com

\begin{abstract}
Vascular and cardiac disease remains a leading cause of morbidity and mortality in developed and emerging countries. Vascular and cardiac interventions require extensive fluoroscopic guidance to navigate endovascular catheters. X-ray fluoroscopy is considered the current modality for real time imaging. It provides excellent spatial and temporal resolution, but is limited by exposure of patients and staff to ionizing radiation, poor soft tissue characterization and lack of quantitative physiologic information. MR fluoroscopy has been introduced with substantial progress during the last decade. Clinical and experimental studies performed under MR fluoroscopy have indicated the suitability of this modality for: delivery of ASD closure, aortic valves, and endovascular stents (aortic, carotid, iliac, renal arteries, inferior vena cava). It aids in performing ablation, creation of hepatic shunts and local delivery of therapies. Development of more MR compatible equipment and devices will widen the applications of MR-guided procedures. At post-intervention, MR imaging aids in assessing the efficacy of therapies, success of interventions. It also provides information on vascular flow and cardiac morphology, function, perfusion and viability. MR
\end{abstract}

M. Saeed $(\varangle) \cdot$ S. W. Hetts · J. English - M. Wilson

Department of Radiology and Biomedical Imaging,

University of California San Francisco,

185 Berry Street, Suite 350, Campus Box 0946,

San Francisco,

CA 94107-1701, USA

e-mail: Maythem.Saeed@radiology.UCSF.edu fluoroscopy has the potential to form the basis for minimally invasive image-guided surgeries that offer improved patient management and cost effectiveness.

Keywords Cardiac imaging .

Magnetic resonance imaging · Vascular imaging

\section{Introduction}

The rapid evolution of minimally invasive vascular and cardiac interventions is shaping the demand for high temporal and spatial resolution imaging that offers safety, accuracy, flexibility and functionality. Recent improvements in signal processing, tissue characterization and angiographic integration allowed MR-guidance in complex interventional procedures, which require optimal spatial resolution and orientation [1, 2]. MR fluoroscopy offers rapid acquisition, reconstruction and display of 3D images. Therefore, it has been used in biopsies [3-7], brachytherapy [8, 9], focused ultrasound [10-13], thermometry [10, 14-17], functional imaging integrated into MR guided neurosurgical interventions [18, 19], local drug delivery [20, 21], endoscopy [22], intravascular interventions [23-34] and intra-operative imaging [19, 35-40].

X-ray fluoroscopy

$\mathrm{X}$-ray fluoroscopy is routinely used in patients to guide vascular and cardiac interventions, because of 
its ability for real-time imaging and easy access to patients during interventions [41-43]. X-ray fluoroscopy, however, is limited for defining soft tissue and obtaining functional information. The poor contrast between pathologic and healthy surrounding tissue hinders X-ray fluoroscopy in defining targets [44], which subsequently leads to blind delivery of therapies to the targets $[20,45]$. Furthermore, there is a growing body of evidence that exposure to ionizing radiation from $\mathrm{X}$-ray procedures is associated with an increased risk of cancer [46-50].

Interventional MR magnets

Different MR magnet designs have been developed, namely open and hybrid, for MR guided vascular and cardiac interventions [51]. Open magnets were designed to ease patient access. Both open and double donut XMR hybrid magnets use $0.2 \mathrm{~T}$ and $0.5 \mathrm{~T}$ fields and have low gradient strength. These low field magnets offer suboptimal image quality and slow switching speeds that do not meet the need of cardiovascular interventions. For example, Wacker et al. [52] found that $1.0 \mathrm{~T}$ closed-bore halved the procedure time during stent deployment compared to $0.2 \mathrm{~T}$ open-bore magnet. Another hybrid XMR system consists of an angiographic laboratory adjacent to closed-bore 1.5T MR magnet, wherein an on-track patient table could be moved rapidly between the two imaging modalities (Fig. 1a) [53, 54]. More recently, another XMR hybrid system has been developed that has a side-by-side $1.5 \mathrm{~T}$ magnet and $\mathrm{C}$-arm X-ray

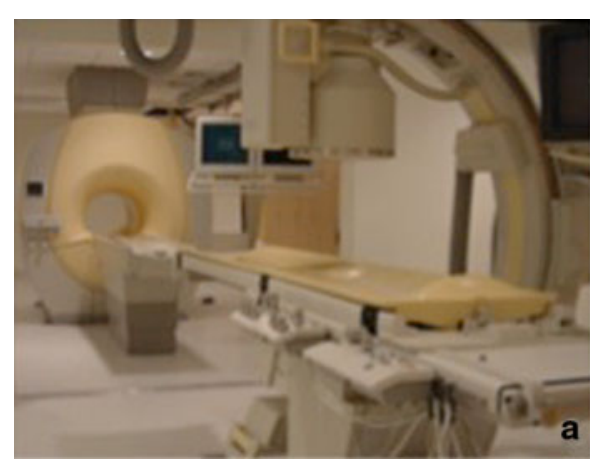

Fig. 1 Two types of hybrid XMR suites equipped with a closed bore 1.5T MR magnet and C-arm X-ray fluoroscopy. The a suite consists of 2 rooms separated by a sliding door (Phillips Medical Systems). The recently developed hybrid system $\mathbf{b}$ is an example of a more advanced facility, where both system (Personal communication) (Fig. 1b). The in-suite operation consoles and display monitors are of great help in instant imaging acquisition and monitoring.

The advantages of hybrid XMR systems are: (1) intermodal movement is minimized because a patient will remain on a sliding table throughout the imaging session; (2) unlike single system, the XMR hybrid system permits evaluation of the impact of interventional procedures via MR monitoring; (3) it permits rapid deployment of catheters, and efficient execution of desired interventions without the obligation of using MR compatible devices; (4) it reduces radiation exposure [55] and (5) offers the convenience of a single visit. However, currently XMR systems are available only in few medical centers.

\section{Devices for MR interventions}

Unfortunately, endovascular catheters and devices are optimized for their mechanical properties and visibility under projection X-ray imaging. There are, therefore, substantial metallic components within the plastic sheath that may be ferrous in nature. Visualization of these commercial endovascular catheters and devices has been difficult on MR imaging due to the susceptibility artifacts derived from the ferromagnetic material, geometry and design [56, 57]. Unlike ferromagnetic material, nickel-titanium alloy (nitinol), platinum, gold, copper, nonbraided or plastic catheters cause substantially less susceptibility artifacts [57-59] and produce less radiofrequency

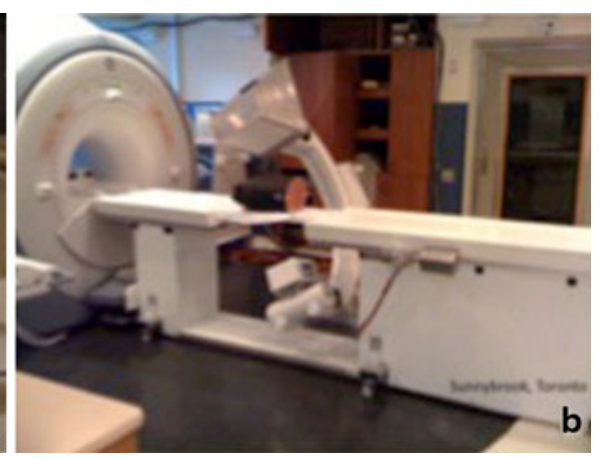

C-arm X-ray fluoroscopy and 1.5T MR systems are in the same room, thereby making interventional procedures shorter and more efficient (courtesy of Dr. Graham Wright, Sunnybrook, Toronto) 
heating in vivo $[60,61]$. Nitinol stents and guidewires are currently used for revascularization of stenosed blood vessels. Mekle et al. [62, 63] used a synthetic MR friendly polymer-based guide-wire for dilatation of an artificial stenosis in phantoms and in the carotid artery, aorta, and iliac arteries of swine [63]. More recently, investigators manufactured a guide wire based on micropultruded fiber-reinforced material doped with iron particles to improve visibility. At the distal part of the guide-wire a nitinol wire was attached to provide flexibility to the tip [64].

In vitro studies showed that MR fluoroscopy can track and navigate nitinol catheters (Fig. 2). At the present time, few prototype catheters have been designed [21, 65-67], but require further investigation. The catheters used for local drug delivery under MR fluoroscopy contain a steering device and needleadjusting scale pistol at one end and a nitinol needle, which is a part of a thin nitinol catheter runs inside the catheter at the other end.

Investigators used three approaches for endovascular catheter tracking and navigation, namely passive tracking (Fig. 3), active tracking (Figs. 2, 3) and magnetic catheter steering (Fig. 4). Investigators also used dysprosium markers mounted on $3 \mathrm{~F}$ non-braided catheters for tracking and visualizing the catheters. The contrast between the catheter and background blood can be improved by injecting MR contrast media, which prevents flow artifacts because the steady state is reached earlier [54, 68]. Bakker et al. [24] were the first to use the passive tracking approach for steering basilica veins of healthy volunteers. Later, this passive approach was adapted by Manke et al. [69] and Razavi et al. in patients [70]. The advantage of this technique is that it requires no hardware or instrument modifications and, thus, appears to be particularly promising in terms of potential clinical applications. The disadvantage is that the catheter disappears when it is out of the image plane due to the motion.

Active tracking is another approach for tracking endovascular catheters (Figs. 2, 3). This technique relies on specially designed micro-coils, electrified wire loop and self-resonant radiofrequency circuits. The coils pick up signal during slice excitation and generate a frequency-encoded recall echo, which can be detected in $3 \mathrm{D}$ at a spatial resolution of approximately $1 \mathrm{~mm}$. The micro coils provide robust tracking of the catheter shaft and tip that allows the user to identify its position and target (Fig. 3) [7174]. Quick et al. [75] used antennas for active catheter tracking and imaging of the abdominal aorta, superior mesenteric artery, renal arteries, hepatic artery and celiac trunk. In another study, they were able to simultaneously visualize vascular tree, catheter shaft and tip [76]. The advantage of this technique is that it allows for visualization of longer portion of the catheter or guidewire when a loopless antenna is placed. On the other hand, the disadvantage includes the need for special hardware and software. Furthermore, the support patient systems, interventional devices and surgical instruments must be MR-compatible. MR-compatible equipment for anesthesia, assessment of physiologic parameters and contrast media injection are currently offered by multiple venders.
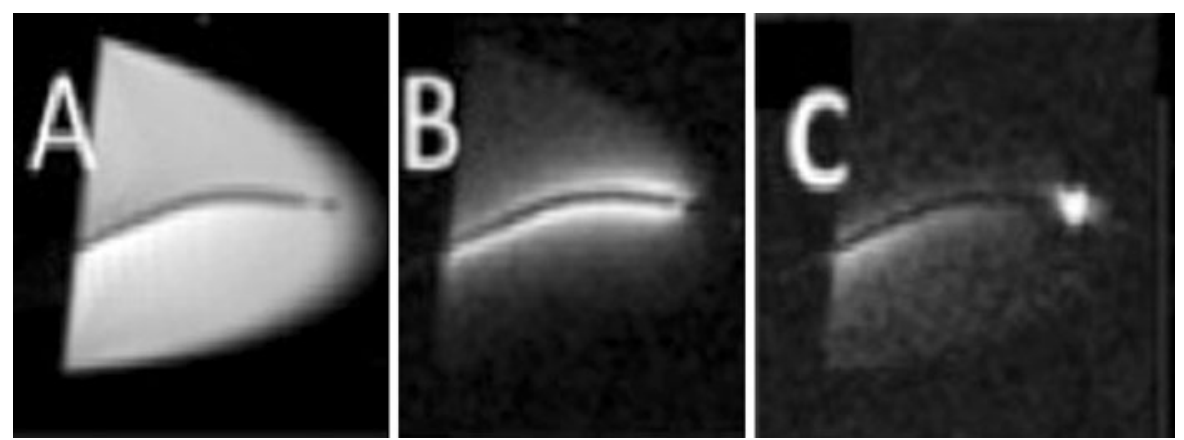

Fig. 2 MR images show the activated coils in a water bath. a Shows the external surface coil elements, $\mathbf{b}$ a coil placed on the shaft of the catheter and $\mathbf{c}$ a coil placed at the catheter tip.
This type of active catheter has been frequently used for transendocardial delivery of stem cells and angiogenic genes 

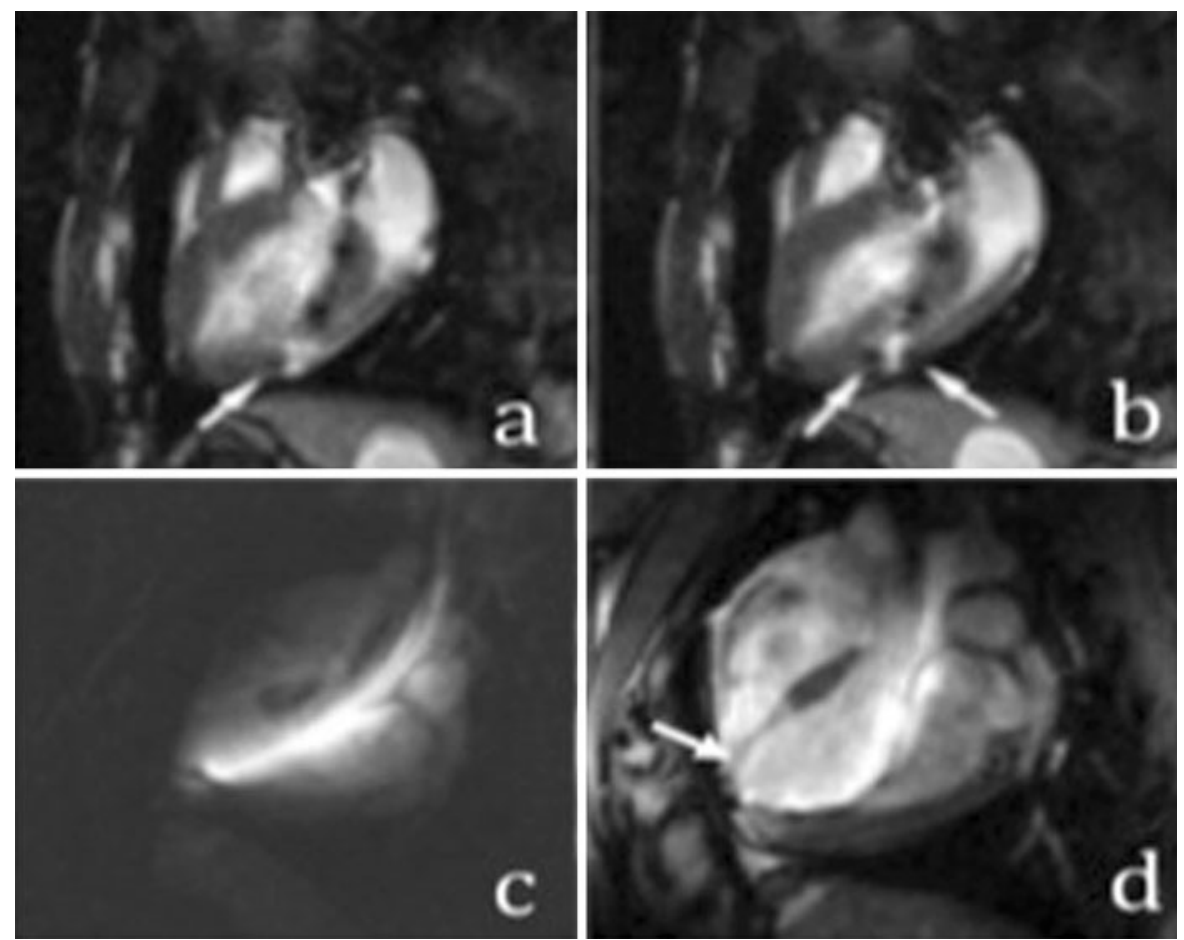

Fig. 3 Selected MR fluoroscopic images show the passive a, b and active c, d catheters in the left ventricle hitting myocardial targets (arrows). The passive catheter is labeled with MR contrast media, while the active catheter wrapped

with coil. Note that the background anatomy of the heart and great vessels can be clearly visualized using both the active catheter and active body coil (d)
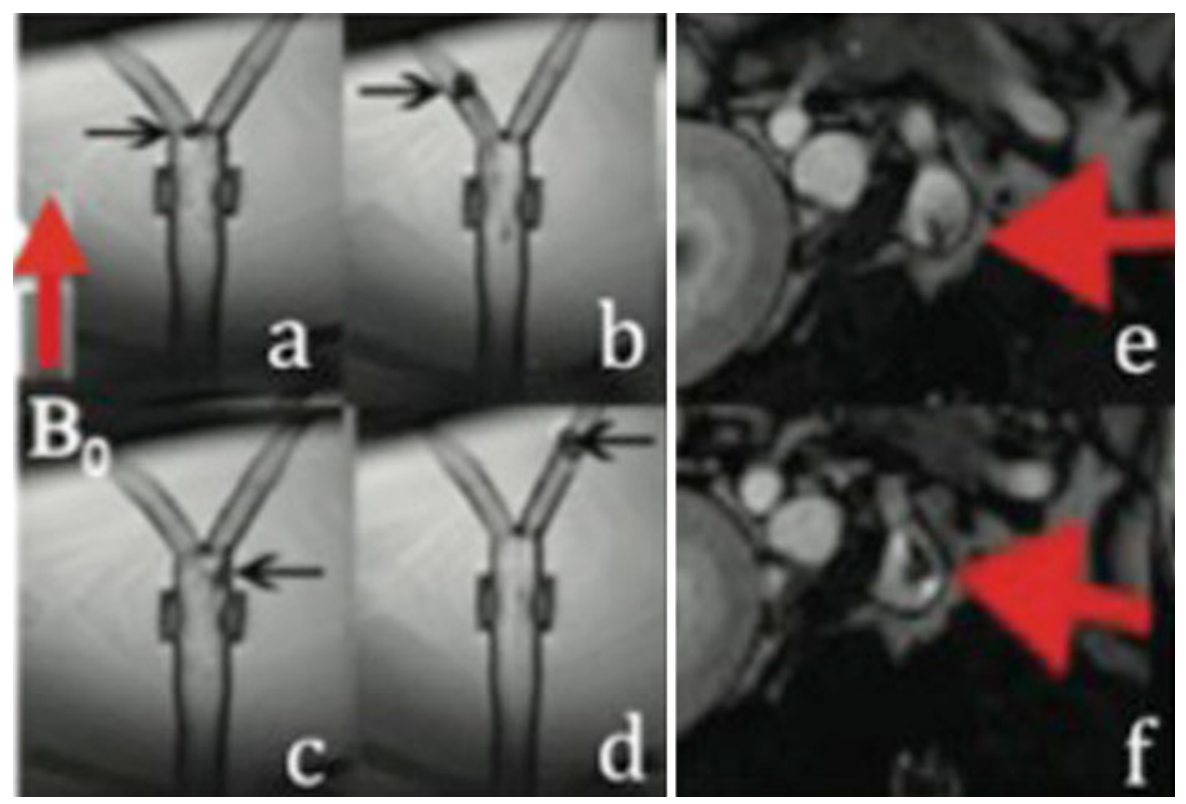

Fig. 4 Dynamic coronal MR images of a $2.5 \mathrm{~F}$ two axis (saddle and helical) coil-tipped catheter deflected and advanced up the left $(\mathbf{a}, \mathbf{b})$ and right $\mathbf{c}, \mathbf{d}$ of a phantom (B0-
Bore of magnet). The in vivo study shows the catheter in the superior mesenteric artery (red arrows, e, f) 
The safety of active endovascular devices is still a major concern. The conductive nature of the long metallic braid creates a safety hazard in the MR environment, as the braided shaft can interact with incident RF energy and the electric field transmitted from the RF coil $[60,61,77]$. The heat created by the active coils causes necrosis of the tissue adjacent to the catheter and blood clotting, which may lead to vascular embolization. The methods for mitigating the potential for heating include using unbraided catheters, insulating the conductive structure, limiting the RF power to which it is exposed, or altering its interaction with the RF energy source [78]. The FDA limits the allowable power deposition via MR imaging to $8 \mathrm{~W} / \mathrm{kg}$ and temperature change to $2^{\circ} \mathrm{C}$. Patients with internalized devices containing long conductive structures, such as deep brain stimulators [79] and cardiac pacemakers [80-82], are presently scanned with MR imaging provided additional safety steps are taken. These typically include heightened patient monitoring, lower permissible specific absorption rate levels, and the use of local transmit RF coils.

Magnetic catheter steering is a new approach for tracking endovascular catheters using remote control [83]. It relies on a small magnetic moment created by application of an electrical current to copper coils on the catheter tip, which results in alignment of the catheter in the direction of the $\mathrm{B}_{0}$ field (Fig. 4) [84, 85]. Magnetic catheter steering approach allows for more efficiency in navigating small, tortuous blood vessels, which are currently difficult to catheterize due to build-up of friction at vascular bends. In addition to improved visualization of the endovascular catheter at low power levels, this technology permits deposition of thermal energy for ablation of tissues at higher power levels. This technology is under active investigation [86, 87].

\section{MR contrast media}

MR fluoroscopy and catheter tracking can be expanded using a variety of MR contrast media with high safety profiles [88-90]. Investigators used extracellular and intravascular MR contrast media with $\mathrm{T}_{1}$-enhancing or $\mathrm{T}_{2}$-enhancing capabilities for labeling different types of cells [91, 92]. Extracellular MR contrast media have small molecular weights $(<1 \mathrm{kDa})$, brief plasma half-life and are clinically used in vascular angiography and in assessing myocardial viability. On the other hand, intravascular (blood pool) MR contrast media have high molecular weights $(>50 \mathrm{kDa})$, mass and $\mathrm{T}_{1}$ relaxivity with prolonged plasma half-life. Preclinical experiments showed that intravascular contrast media provide better vascular angiograms. Moreover, contrast media have been used on MR fluoroscopy to improve visualization of endovascular devices [20], in road mapping blood vessels [93, 94] and defining pathologic targets [95]. Investigators also used MR contrast media for labeling different types of cells [91, 92], which assist in monitoring the distribution of the injected cells in vivo [96-98].

A study showed that high dose or repeated administration of gadolinium might be a concern, especially in patients with impaired renal function [99]. This problem can be reduced by paying attention to a glomerular filtration rate of $>30 \mathrm{ml} / \mathrm{min} / 1.73 \mathrm{~m}^{2}$ and contrast agents with high molecular stability [100].

\section{MR fluoroscopy sequences}

MR fluoroscopy became possible because of the major advancements in the speed of data acquisition, data transfer, and interactive control and display. Other factors include highly uniform magnetic fields, rapidly changeable magnetic field gradients, multichannel receivers and computing systems. MR fluoroscopy sequences achieve their high speeds by maximizing the switching rates of gradients and RF pulses. The temporal and spatial resolution in MR fluoroscopy are often complementary factors. The speed of imaging is determined by how quickly spatial encoding can be performed and how fast k-space data can be acquired. Actively shielded, strong, fast-switching gradients and fast electronics have allowed data acquisition intervals to be reduced.

Fast MR imaging techniques have been developed in recent years, allowing frame rates almost comparable to those achieved with X-ray fluoroscopy. Most modern real-time MR implementations employ balanced steady state free precession techniques because of efficient use of magnetization, high SNR, and short repetition times [101-103]. The performance of these sequences is currently in the range needed to perform MR guided procedures at $>5 \mathrm{fps}$ [104]. The SSFP acquisitions have been performed using radial [105], and spiral [106] k-space trajectories. These acquisition techniques in conjunction with spiral or radial filling of 
the k-space are considered very reliable for high spatial and temporal resolutions. These imaging sequences also benefit from the use of multiple receiver coil elements [107-109]. Parallel imaging accelerates acquisition by using the different spatial sensitivities of the coils to correct for under-sampling of image data [110]. Other sequences that can improve imaging speed while simultaneously balancing imaging quality include non-Cartesian k-space sampling, temporal data sharing between images, and adjusting the tradeoff between temporal and spatial resolution [102]. The use of 32 channel receiver arrays that will perform rapid 3D cardiac imaging and parallel transmission techniques to permit more efficient parallel data collection are also under active investigation [111]. It should be noted that MR fluoroscopy is not free of limitations. For example, the closed configuration of MR magnets $>1.5 \mathrm{~T}$ limit access to the patient and RF pulses induce heating when conductive material is applied in devices; MR imaging has relatively low spatial and temporal resolution compared with X-ray fluoroscopy; and is sensitive to magnetic field inhomogeneity, pulsatility and motion of spins and chemical shift.

In pre and post-intervention the following MR sequences were used: (a) balanced fast field echo CINE images for measuring LV volumes, ejection fraction, cardiac output, stroke volume, LV mass, wall thickness and radial strain [90, 112-114], (b) tagged gradient echo planar imaging for measuring circumferential strain and LV rotation [115, 116], (c) phase-contrast velocity-encoded gradient echo planar imaging for measuring longitudinal strain [117], (d) $\mathrm{T}_{2}$-weighted turbo spin echo sequence for measuring interstitial edema after ablation, (e) $\mathrm{T}_{2} *$ multi-echo gradient echo sequence for measuring vascular and myocardial hemorrhage after intervention [118], (f) $\mathrm{T}_{1}$-weighted gradient echo (radiofrequency spoiled) perfusion imaging sequence for measuring myocardial perfusion changes after delivery of therapy, and (g) delayed contrast enhanced 3D $\mathrm{T}_{1}$-weighted gradient echo sequence for assessing tissue viability.

Applications of MR fluoroscopy

\section{Vascular interventions}

MR imaging provides detailed information on vascular layers and is able to differentiate between plaque components, such as fibrous, lipid rich and calcified tissue $[119,120]$. In the last decade MR imaging has been extended from a diagnostic to a dynamic modality, which can be used to guide intravascular guidewires and catheters and to assess the success of endovascular procedures. In 1997 the first human MR-guided study was performed and showed excellent visualization of an endovascular catheter labeled with dysprosium ring markers [24]. In this study, investigators did not use guide wires during the movement of the catheter in the cephalic vein of healthy volunteers. Later, MR-guided percutaneous transluminal angioplasty has been conducted without complications in 13 patients with iliac stenosis [121] and in 15 patients with femoral and popliteal artery stenosis [122].

MR-guided procedures (stenting and/or angioplasty) have been performed for dilatation of the aorta, pulmonary, coronary, renal iliac and femoral arteries [45, 57, 121-124]. MR-guided imaging has been used for delivery of stents in major and minor blood vessels [45, 52, 57, 125-131]. Vascular stents, vena cava filters, cardioseptal occluders or prosthetic heart valves require, however, post-interventional follow-up, which are usually made under X-ray or CT. MR imaging, with its superior soft-tissue contrast, arbitrary slice orientation and flow measurement would be the preferred imaging technique; however, most conventional vascular implants made of metal create image artifacts and masked visualization of the lumen. The three main types of MR artifacts associated with metallic vascular implants are susceptibility artifacts, flow-related artifacts and $\mathrm{RF}$ artifacts. Active MR resonant stents provide noninvasive visualization of instant thrombosis and restenosis without the need for MR contrast media. Visualization of the lumen of vascular implants is important for a safe and reliable examination on MRguided procedures.

Mahnken et al. used MR-guided procedures for placement of aortic stents grafts [132]. More recently, Kos et al. used a polyetheretherketone-based MR imaging-compatible guidewire in swine for aortic stenting and vena cava filter placement [133]. Several groups have successfully used MR-guidance for placement of vena cava filters [134, 135]. Pulmonary artery stents have also been accurately implanted across the pulmonary valve $[57,58,136]$. It should be noted that only a few investigators have performed 
vascular stenting in patients under MR guidance [121, 122]. Manke et al. [121] successfully deployed stents under MR-guidance in iliac arterial stenosis in patients. Post-interventional MR imaging showed the localization and function of the stents. MR fluoroscopy has been recently used for assessment of the pulmonary arterial pressure in pediatric and adult patients with congenital heart disease [70, 137]. A variety of MR-guided interventions have been performed in patients with congenital heart diseases including; placing transjugular, intrahepatic portosystemic stents, radiofrequency ablation, aortic coarctation, atrio-septal defect (Fig. 5) and cardiac catheterization. In 2006, Krueger et al. performed the first MR-guided study using balloon angioplasty for treating aortic coarctation in 5 patients. This was an important step toward MR-guided treatment of this congenital disease [138].

Kuehne et al. [139] demonstrated successful implant of a self-expanding stent valve in the aorta via percutaneous access under MR fluoroscopy. Transcatheter aortic valve implantation, either retrograde through a transfemoral approach or antegrade through a transapical approach, has become a clinical reality in the treatment of critical aortic stenosis in high-risk patients. MR fluoroscopy plays an important role in transcatheter aortic valve implantation and replacement of insufficient aortic or pulmonic valves [57, 58, 136]. MR imaging enables accurate and reproducible quantifications of regurgitate fraction before and after valve placement. Under MR fluoroscopy, McVeigh et al. [140] used apical access to guide the placement of a prosthetic aortic valve in beating heart. MR imaging offered the visualization of both coronary ostium during stent implantation and allowed aortic flow assessment.

\section{Cardiac interventions}

Percutaneous closure of atrio-septal defects and ventriculo-septal defects is increasingly performed under $\mathrm{X}$-ray, which brings the disadvantages of ionizing radiation and lack of soft-tissue contrast. MR imaging is a technique that provides high-resolution 3D images of the heart. Three-dimensional MR imaging before intervention is particularly important because it improves our understanding of the anatomic basis of complex arrhythmias. Closure of such congenital defects under MR-guidance has been proved in animals [141], but is hampered by image artifacts produced by the materials of the closure devices and the use of fast sequences for cardiac imaging [142]. Few studies showed that MR imaging is useful for arrhythmic substrate identification [143, 144].

MR-guided procedures have been successfully used in thermal ablation and after intervention to assess the success of ablation [145-150]. Clinical studies showed atrial scar on contrast enhanced MR imaging that results from RF ablation [151-153]. Other studies have demonstrated the association

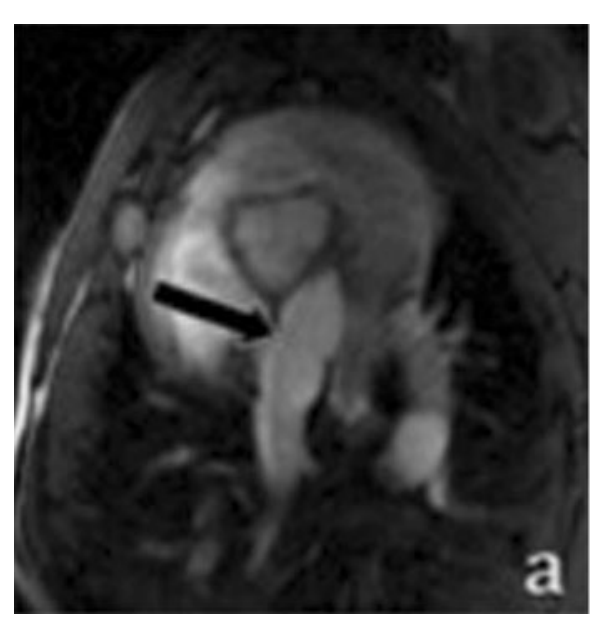

Fig. 5 A balloon at the tip of endovascular catheter (arrow) filled with MR contrast medium (a), and CT contrast medium (b), used for sizing ASD under MR (a), and X-ray fluoroscopy

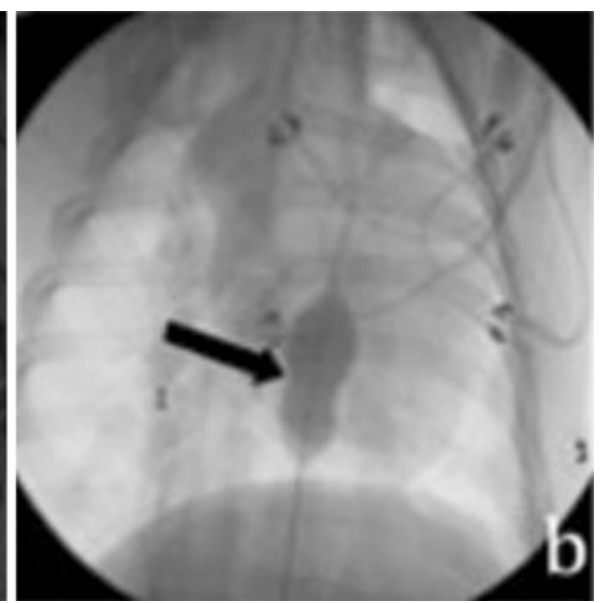

(b). Note the close estimate of the waist (arrows), representing the ASD diameter 
between infarct scar, border-zone and the risk of monomorphic ventricular tachycardia $[144,154$, 155]. Dong et al. found that $3 \mathrm{D}$ MR imaging is helpful for tailoring ablations to the variant pulmonary vein anatomy in $47 \%$ of patients with atrial fibrilation [156]. They also noted that 3D images of the atria helped in localizing areas along the tissue ridge separating the left atrium from the pulmonary vein $[156,157]$. The ability of MR fluoroscopy to visualize the needle tip in the inferior vena cava, atria, fossa ovalis, and surrounding vasculature during transseptal cardiac punctures has also been demonstrated [158-161].

Atrial septal defect (ASD) is another congenital defect common in children, leading to heart failure and pulmonary hypertension. Percutaneous transcatheter delivery of an ASD occluder has been performed on X-ray fluoroscopy [162]. A recent study showed that MR imaging provides reliable diagnosis of ASD [163]. Substantial experience has been obtained in animal models where MR fluoroscopy was used for delivery of ASD closure [164, 165] and sizing of the ASD (Fig. 6) [166]. The ASD occluders, delivered on MR fluoroscopy, are made of a nitenol mesh to reduce the artifacts [161]. Others used a commercial nitinol snare coaxial catheter system for delivering septal occluders [166]. Schalla et al. [161] simulated clinical-grade pediatric diagnostic catheterization in an animal model of ASD. The advancement of the delivery system through the IVC to the right atrium was monitored under MR fluoroscopy (Fig. 7). In another study, they advanced an active catheter, under MR fluoroscopy, to right and left sides of the heart and invasively measured pressure and oxygen in both right and left sides of the heart [70, 161] (Figs. 7, 8). Measurements of flow from velocity encoded MR imaging and blood pressure from the catheter were used to calculate pulmonary resistance. The flow and resistance data obtained from Fick and MR cardiac catheterization methods were in agreement [70, 161], suggesting accurate physiologic data can be obtained on MR imaging.

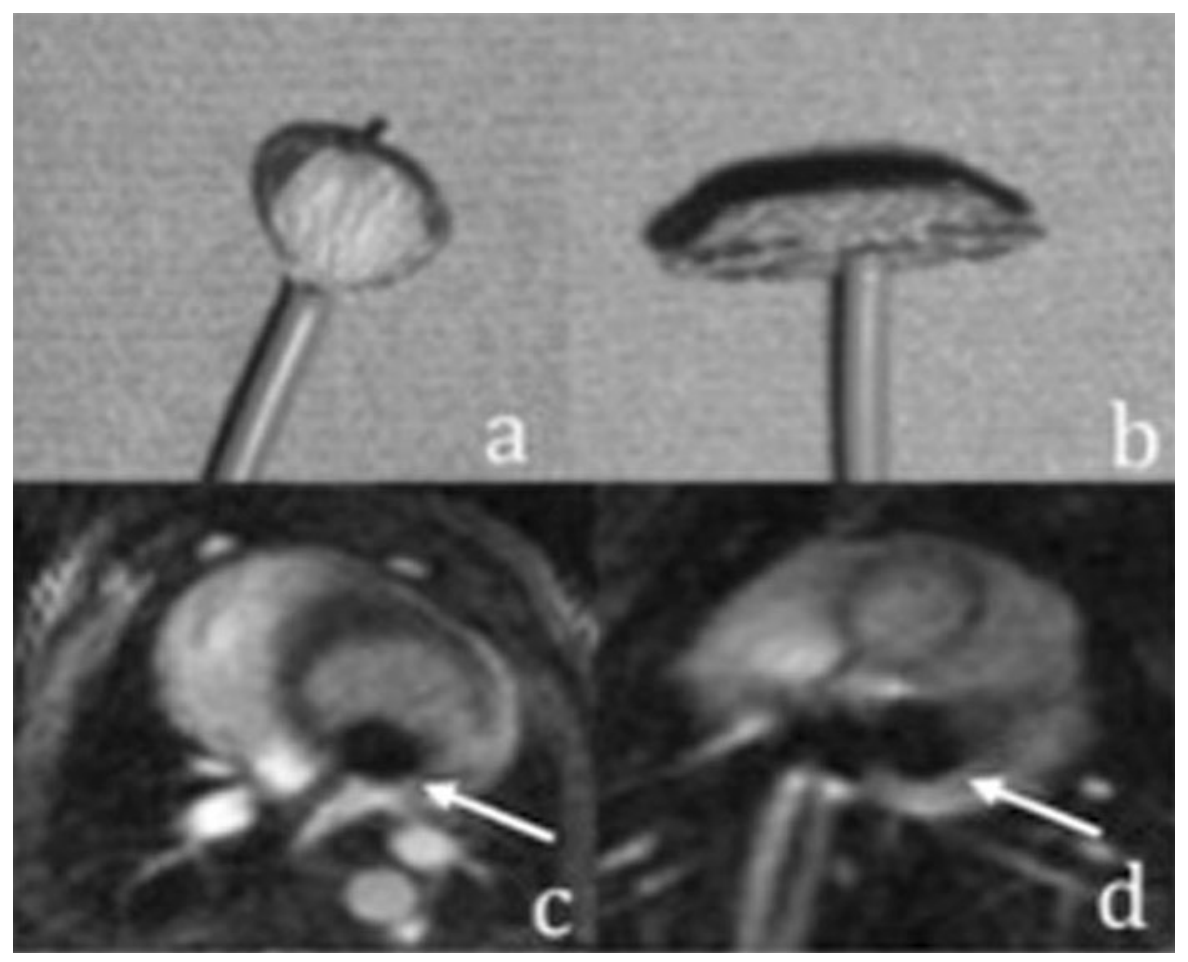

Fig. 6 Simulation of deployment of the septal occluder device in vitro $(\mathbf{a}, \mathbf{b})$, and corresponding selected real-time $\mathrm{MR}$ images in vivo (c, d). The device was easily detected as a signal void on real time MR images. The closure device was advanced inside the delivery sheath until the folded first disk appeared (c) followed by the release of the second disk in the right atrium $(\mathbf{d})$ 


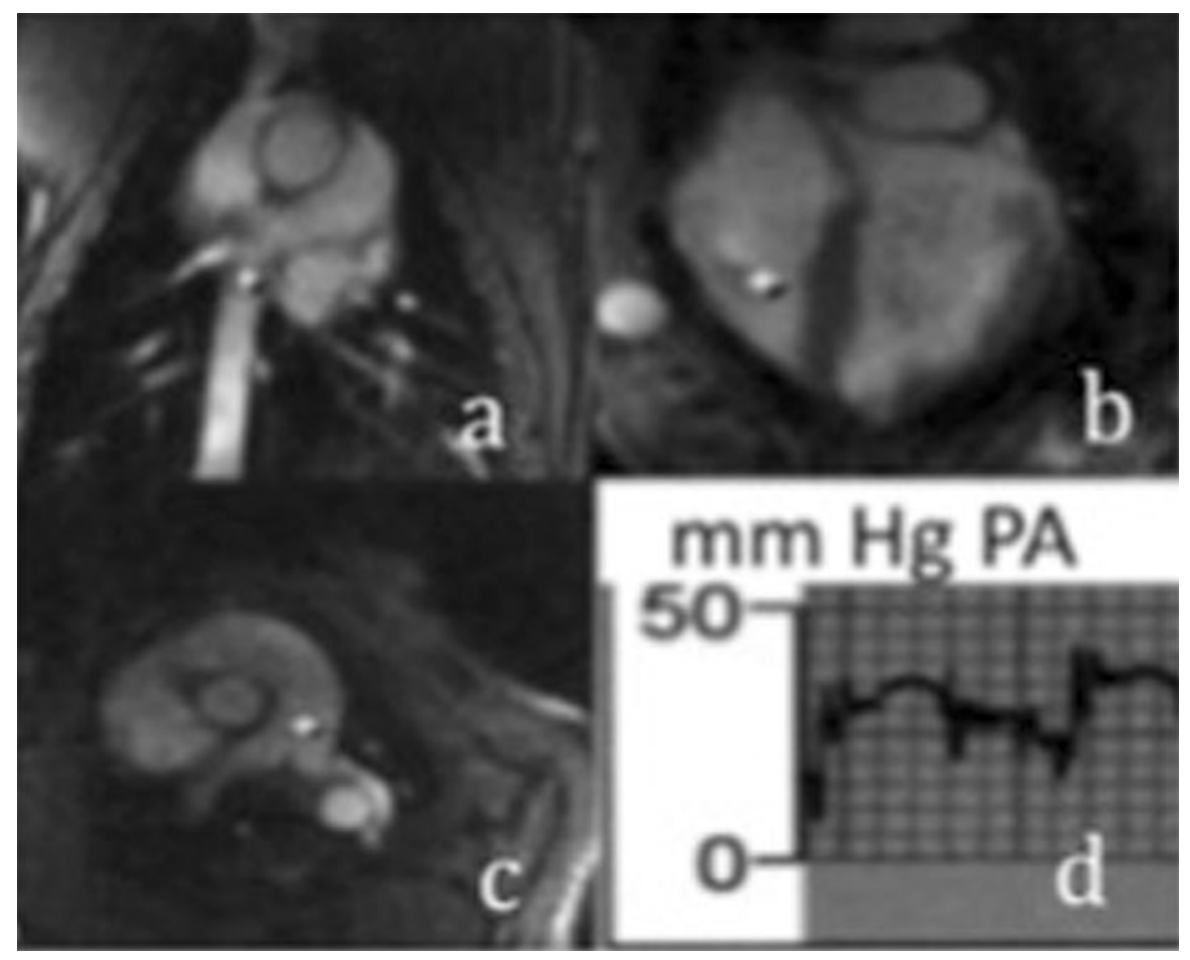

Fig. 7 Catheterization of main pulmonary artery under MR-guidance. Image planes: inferior vena cava (a), right ventricular outflow tract (b), and outflow-tract- pulmonary artery (c) and a pulmonary artery pressure curve in $\mathrm{mm} \mathrm{Hg}(\mathbf{d})$
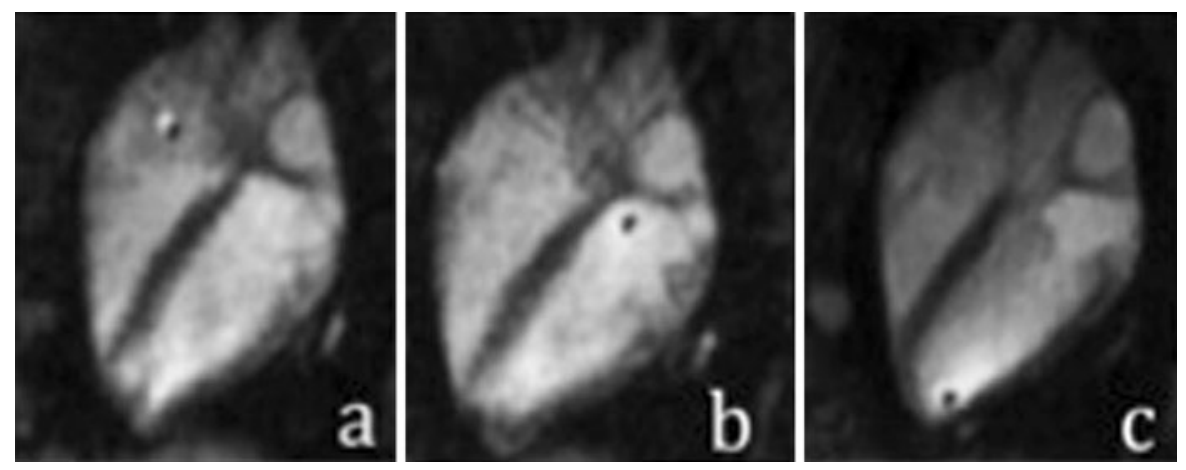

Fig. 8 Selected MR fluoroscopy images show antegrade catheterization of LV (femoral venous/transseptal access). The images show advancement of tracking catheter from RA (a), transseptally into LA (b), and LV (c). Catheter tip is detected as a cross

A recent study in 10 patients and 5 volunteers showed that MR fluoroscopy is suited to guide flow directed catheters for measurement of invasive pulmonary artery pressures [167]. Pulmonary vascular flow was noninvasively measured using velocity-encoded cine MR imaging, while pulmonary pressure was measured invasively through a catheter guided into the pulmonary artery under MR-guidance. The results indicate that MR imaging is a promising tool for measurement of pulmonary vascular resistance in patients with different degrees and forms of pulmonary hypertension. MR fluoroscopy has also been used in connecting cardiac chambers and blood vessels in a swine model, where Arepally et al. connected the right and left atrium by puncturing the interatrial septum using an active Brockenbrough-style needle [168]. In a clinical study in seven patients, Dick et al. conducted 
trans-septal puncture and balloon septostomy under MR fluoroscopy [169].

MR guided delivery of genes and stem cells

Vascular and cardiac disease is a major public and economic health problem leading to more than 7 million deaths world wide each year. Current treatments of this disease include pharmaceutical drugs, deployment of devices and interventional therapies. These method, however were unable to replace necrotic, apoptotic cells and damaged vessels by new cardiomyocytes or blood vessels. Clinical studies confirmed that there are an increasing number of patients who have persistent chronic angina, despite having multiple coronary revascularization procedures. Heart transplantation is the definitive therapy for these patients, but this option is limited to $\sim 2,000$ donor hearts annually. Thus, there is a mandate for alternative treatment and minimally invasive approaches, such as endovascular catheterbased techniques, for local delivery of new therapies to restore cardiomyocytes and blood vessels. Angiogenic growth factor, gene and stem cell therapy have been recently used as an alternative treatment to restore cardiomyocytes and blood vessels in end stage patients, in combination with coronary artery bypass grafting [170-175]. Recent preclinical and clinical studies showed that percutaneous intramyocardial and intraarterial delivery of therapies is possible [176-180], but Hou et al. found that 11, 2.6 and 3.2\% of the delivered cells are retained in the myocardium after intramyocardial, intracoronary, and interstitial retrograde coronary venous delivery [181].

Local delivery approaches include surgical and catheter-based delivery of various types of angiogenic proteins, genes and stem cells. Open-chest surgery, however, is impractical in end-stage patients because this strategy increases morbidity and mortality as well as limiting the feasibility of repeat administration [182]. The advantages of catheterbased local delivery of therapies are: (1) targeting only the diseased region, (2) delivering a high local dose, (3) eliminating a high systemic dose and side effects and (4) reducing the chance of angiogenesis in hidden tumor sites especially in elderly patients [170-175, 183].

Gene therapy is a new approach for treating ischemic heart disease and it is an exciting area of modern medicine. Recent MR-guided studies demonstrated the success of catheter-based transendocardial delivery of genes (Fig. 2). Preclinical studies have indicated that MR imaging provides quantitative data on infarct size, infarct transmurality, microvascular obstruction and hemorrhage). These capabilities have positioned MR imaging as an important approach to persue for assessing the benefits of locally delivered genes [20]. The MR-guided approach for delivering plasmid-VEGF gene has been validated using histopathology as a gold standard, which ensured the efficacy of delivered therapy into infarcted myocardium by demonstrating the formation of new blood vessels in treated animals (Fig. 9). Another MR study showed the increase in collateral blood flow of infarcted myocardium after delivering vascular endothelial growth factor [184]. Post et al. [185] demonstrated an improvement in regional radial strain after intramyocardial injection of adenovirus coding for P39 gene. Furthermore, Liu et al. found a significant improvement in LV ejection fraction and smaller number of segments with wall motion abnormality after intramyocardial injection of fibroblast growth factor [186].

Stem cell transplantation is another approach for treating ischemic heart disease as it improves cardiac function and revascularizes ischemic myocardium. The therapeutic effect of stem cells seems to be related to the release of angiogenic factors rather than trans-differentiation of delivered stem cells. Two predominant routes for stem cell delivery to infarcted myocardium are intracoronary infusion and direct intramyocardial injection. Each of these delivery routes attempts to maximize the retention of delivered cells to infarcted myocardium namely. Early clinical studies indicated that cell transplantation, delivered under MR fluoroscopy, is safe and feasible [97, 187-189]. MR imaging has been used not only to track stem cells in the myocardium, but also to noninvasively evaluate ventricular function, perfusion and viability [190]. Cell tracking on MR imaging is based on labeling injected cells with US FDA approved super paramagnetic iron oxide particles [189, 191]. It has been shown that iron labeled cells maintain their viability, proliferation and differentiation [97]. The cluster of iron labeled cells appear dark on $\mathrm{T}_{2} *$ and $\mathrm{T}_{2}$ MR images [189, 191, 192]. Several factors affect the detection of labeled cells, which include the (1) magnetic field, (2) labeling 


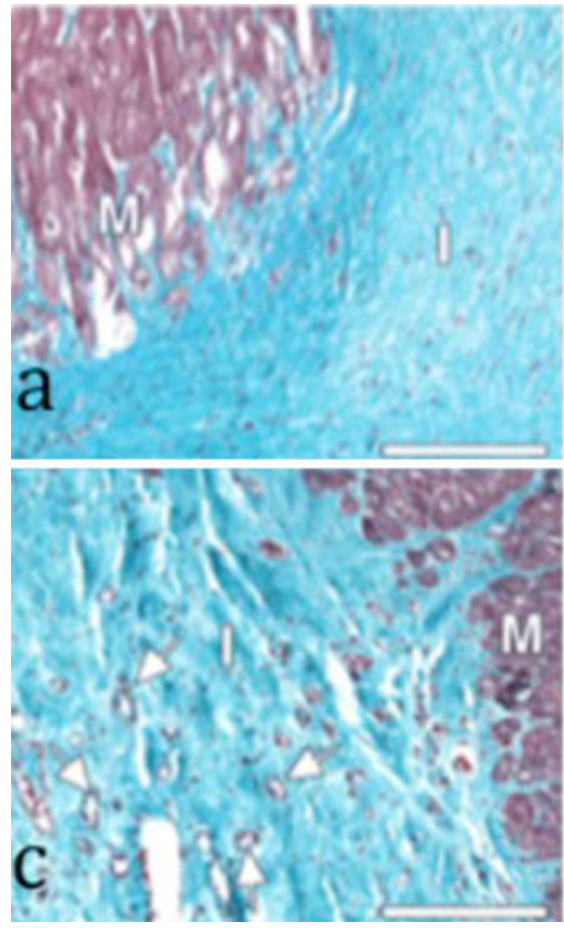

Fig. 9 Photomicrographs of representative infarctions in control $(\mathbf{a}, \mathbf{b})$ and VEGF gene-treated animals $(\mathbf{c}, \mathbf{d})$. Sections $\mathbf{a}$ and $\mathbf{c}$ were stained with Masson trichrome stain, while $\mathbf{b}$ and d were stained with biotinylated isolectin B4. Sections a and c show chronic infarction $(I)$ in both groups which is comprised of homogeneous replacement fibrosis with a distinct boundary at the interface between scar and viable myocardium $(M)$.

efficiency, (3) type of cells and (4) time of imaging after delivery. Investigators found that the duration of MR detection varies between cells; up to 5 weeks for embolic stem cells [193] and up to 16 weeks for skeletal myoblasts [194]. Investigators also found hypo-intense tiny regions far from the site of injection, indicative of migration of stem cells within the infarction several weeks after delivery. MR imaging was used to evaluate changes in LV remodeling following the delivery of cellular therapy [98, 195-199]. Amado et al. [200] were able to identify a time-dependent recovery of local contractility associated with the appearance of new tissue resulting from transplantation of allogeneic stem cells in a pig model of myocardial infarct.

Recent randomized clinical trials demonstrated the safety of bone marrow mononuclear treatment after intracoronary injection [201, 202]. Promising clinical results from intracoronary delivery of autologous bone marrow derived stem cells and progenitor cells

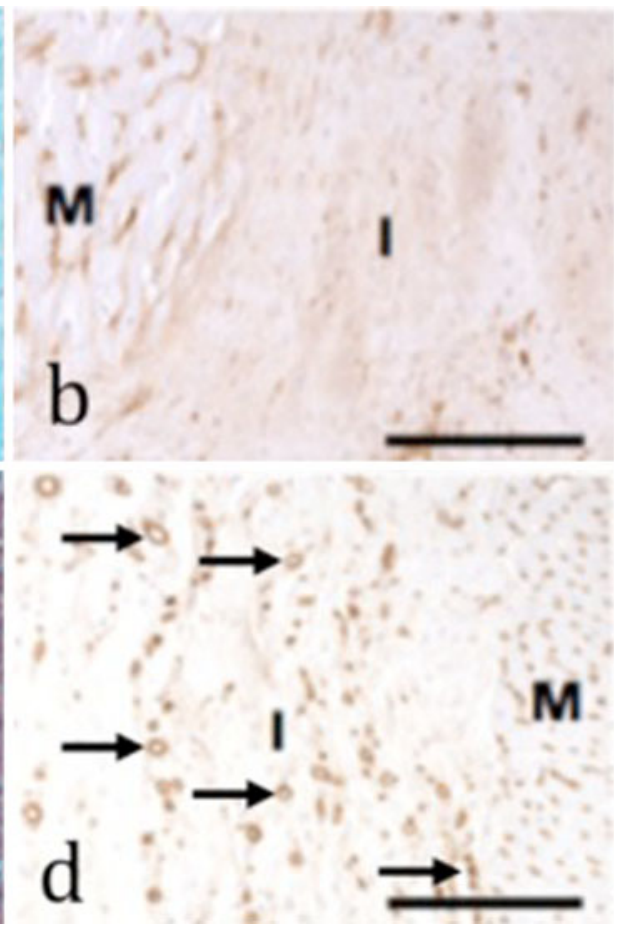

Treated animal contained numerous vessels c, d) (arrows), while control infarction contained very few vessels. Biotinylated isolectin B4 localized vessels with brown reaction product, accentuating the neovascularity in VEGF gene-treated infarct (d) as compared with infarct in control animal (b). Calibration bars $=80 \mu \mathrm{m}$

showed improved myocardial function [201, 203206]. The proposed mechanisms of protection by stem cells include angiogenesis via the release of angiogenic factors, myogenesis, cytoprotection via the release of paracrine factors, recruitment of stem cells and suppression of inflammation [207]. More recent 5 year follow-up studies showed that cell therapy causes no significant improvement in LV ejection fraction compared to placebo [208, 209]. Major limitations of intracoronary delivery include: (1) no delivery access to infarct related to permanent coronary artery occlusion; (2) inadequate cellular migration into the interstitial space during the first pass transit; (3) microembolization [210]; (4) systemic delivery to non-cardiac tissue [211] and (5) possibility of intimal dissection [212]. It has been shown that approximately $2 \%$ of intracoronary delivered bone marrow mononuclear cells were retained by infarcted myocardium in humans, but when the investigators used enriched bone marrow 
mononuclear cells the retention increased to $14-39 \%$ [213].

Ripa et al. [214] used MR imaging to monitor the changes in LV function after subcutaneous granulocytes colony stimulating factor (G-CSF) injection in patients with ST-elevated infarct. They found that G-CSF caused no improvement in LV function. Investigators used different types of cells, such as progenitor cells, myocytes, adipocytes, fibroblasts, and smooth muscle cells, in patients with ischemic heart disease [202, 203, 214-223]. Three randomized controlled studies have been published using bone marrow cells for promoting angiogenesis [202, 203, 218]. In the BOOST study 60 patients were enrolled to evaluate the effect of intracoronary autologous bone marrow cells after myocardial infarction [203]. MR imaging showed a significant increase in ejection fraction from 50 to $57 \%$ in treated patients versus $51-52 \%$ in untreated patients [203]. A more recent update from the BOOST study found the beneficial effects of bone marrow cells were sustained at 18 months [219]. Several complications have been reported after local delivery of growth factor and cell therapies including hemangioma [224], in-stent stenosis and hyperplasia [225] as well as arrhythmia [226].

\section{Summary}

During the last decade medical imaging and minimally invasive cardiovascular interventions have made substantial progress. Improvements in temporal resolution, tissue component characterization and angiographic integration have allowed guidance in complex interventional procedures. MR imaging provides 3D datasets, excellent soft-tissue contrast, multi-planar views, dynamic imaging in a single imaging session and guidance of interventional vascular and cardiac procedures. MR imaging allows monitoring of treatment success after intervention that is not available on X-ray fluoroscopy. These advantages of MR imaging are complementary to its potential advantage against the harmful effects of $\mathrm{X}$-ray guided procedures. In recent studies, balloon dilation, stent placement, valvar replacement, atrial septal defect closure, radiofrequency ablation and local gene and cell delivery have been shown to be feasible. In addition, MR-guided procedures involving gene or stem cell therapy represent a new discipline whose systematic development will foster minimally invasive interventional procedures and will hasten the identification and deployment of effective new therapies for revascularization and myogenesis.

At present, cardiovascular interventions are addressed by multimodality imaging using computed tomography, invasive angiography and transesophageal echocardiography. Whether MR is suited to obviate the need for multimodality imaging is currently unclear and needs to be further evaluated. Furthermore, the availability of safe MR compatible devices will guide future minimally invasive cardiovascular procedures. MR-guided percutaneous transluminal angioplasty and vascular implants placements (such as stents, vena cava filters, heart valves) are examples of future clinical applications.

Catheter-based MR guidance enables a substantially reduced level of invasiveness compared with open-chest surgery, potentially resulting in treatment on an outpatient basis, rapid patient recovery, eliminate radiation exposure and cost savings to the health care system. It should be noted, however, that translation of MR-guided interventions to clinical use has been very slow due to limited availability of MR-friendly catheters, wires, devices and financial funding by National Institute of Health and venders.

Open Access This article is distributed under the terms of the Creative Commons Attribution Noncommercial License which permits any noncommercial use, distribution, and reproduction in any medium, provided the original author(s) and source are credited.

\section{Conflict of interest None.}

\section{References}

1. Saybasili H, Faranesh AZ, Saikus CE, Ozturk C, Lederman RJ, Guttman MA (2010) Interventional MRI using multiple 3D angiography roadmaps with real-time imaging. J Magn Reson Imaging 31(4):1015-1019

2. de Silva R, Gutierrez LF, Raval AN, McVeigh ER, Ozturk C, Lederman RJ (2006) X-ray fused with magnetic resonance imaging (XFM) to target endomyocardial injections: validation in a swine model of myocardial infarction. Circulation 114(22):2342-2350

3. Adam G, Bucker A, Nolte-Ernsting C, Tacke J, Gunther RW (1999) Interventional MR imaging: percutaneous abdominal and skeletal biopsies and drainages of the abdomen. Eur Radiol 9(8):1471-1478

4. Hall WA, Martin AJ, Liu H, Nussbaum ES, Maxwell RE, Truwit CL (1999) Brain biopsy using high-field strength interventional magnetic resonance imaging. Neurosurgery 44(4):807-813 (discussion 813-804) 
5. Heywang-Kobrunner SH, Heinig A, Pickuth D, Alberich T, Spielmann RP (2000) Interventional MRI of the breast: lesion localisation and biopsy. Eur Radiol 10(1):36-45

6. Mueller PR, Stark DD, Simeone JF, Saini S, Butch RJ, Edelman RR, Wittenberg J, Ferrucci JT Jr (1986) MRguided aspiration biopsy: needle design and clinical trials. Radiology 161(3):605-609

7. Steiner P, Erhart P, Heske N, Dumoulin CL, von Schulthess GK, Debatin JF (1997) Active biplanar MR tracking for biopsies in humans. AJR Am J Roentgenol 169(3):735-738

8. D’Amico A, Cormack R, Kumar S, Tempany CM (2000) Real-time magnetic resonance imaging-guided brachytherapy in the treatment of selected patients with clinically localized prostate cancer. J Endourol 14(4): 367-370

9. Popowski Y, Hiltbrand E, Joliat D, Rouzaud M (2000) Open magnetic resonance imaging using titaniumzirconium needles: improved accuracy for interstitial brachytherapy implants? Int J Radiat Oncol Biol Phys 47(3):759-765

10. Cline HE, Hynynen K, Hardy CJ, Watkins RD, Schenck JF, Jolesz FA (1994) MR temperature mapping of focused ultrasound surgery. Magn Reson Med 31(6):628-636

11. Cline HE, Hynynen K, Watkins RD, Adams WJ, Schenck JF, Ettinger RH, Freund WR, Vetro JP, Jolesz FA (1995) Focused US system for MR imaging-guided tumor ablation. Radiology 194(3):731-737

12. Hynynen K, Freund WR, Cline HE, Chung AH, Watkins RD, Vetro JP, Jolesz FA (1996) A clinical, noninvasive, MR imaging-monitored ultrasound surgery method. Radiographics 16(1):185-195

13. Schenck JF (1996) The role of magnetic susceptibility in magnetic resonance imaging: MRI magnetic compatibility of the first and second kinds. Med Phys 23(6):815-850

14. Chung YC, Duerk JL, Shankaranarayanan A, Hampke M, Merkle EM, Lewin JS (1999) Temperature measurement using echo-shifted FLASH at low field for interventional MRI. J Magn Reson Imaging 9(1):138-145

15. Heisterkamp J, Matheijssen NA, van Hillegersberg R, van Vaals JJ, Lameris JS, Stoker J, Jzermans JN (1999) Accuracy of MR phase mapping for temperature monitoring during interstitial laser coagulation (ILC) in the liver at rest and simulated respiration. Magn Reson Med 41(5):919-925

16. Kuroda K, Mulkern RV, Oshio K, Panych LP, Nakai T, Moriya T, Okuda S, Hynynen K, Jolesz FA (2000) Temperature mapping using the water proton chemical shift: self-referenced method with echo-planar spectroscopic imaging. Magn Reson Med 43(2):220-225

17. Patel KC, Duerk JL, Zhang Q, Chung YC, Williams M, Kaczynski K, Wendt M, Lewin JS (1998) Methods for providing probe position and temperature information on MR images during interventional procedures. IEEE Trans Med Imaging 17(5):794-802

18. Gunther RW, Bucker A, Adam G (1999) Interventional magnetic resonance: realistic prospect or wishful thinking? Cardiovasc Intervent Radiol 22(3):187-195

19. Lewin JS, Metzger A, Selman WR (2000) Intraoperative magnetic resonance image guidance in neurosurgery. J Magn Reson Imaging 12(4):512-524
20. Saeed M, Martin A, Jacquier A, Bucknor M, Saloner D, Do L, Ursell P, Su H, Kan YW, Higgins CB (2008) Permanent coronary artery occlusion: cardiovascular MR imaging is platform for percutaneous transendocardial delivery and assessment of gene therapy in canine model. Radiology 249(2):560-571

21. Yang X, Atalar E (2006) MRI-guided gene therapy. FEBS Lett 580(12):2958-2961

22. Hsu L, Fried MP, Jolesz FA (1998) MR-guided endoscopic sinus surgery. AJNR Am J Neuroradiol 19(7): $1235-1240$

23. Atalar E, Kraitchman DL, Carkhuff B, Lesho J, Ocali O, Solaiyappan M, Guttman MA, Charles HK Jr (1998) Catheter-tracking FOV MR fluoroscopy. Magn Reson Med 40(6):865-872

24. Bakker CJ, Hoogeveen RM, Hurtak WF, van Vaals JJ, Viergever MA, Mali WP (1997) MR-guided endovascular interventions: susceptibility-based catheter and near-realtime imaging technique. Radiology 202(1):273-276

25. Bakker CJ, Hoogeveen RM, Weber J, van Vaals JJ, Viergever MA, Mali WP (1996) Visualization of dedicated catheters using fast scanning techniques with potential for MR-guided vascular interventions. Magn Reson Med 36(6):816-820

26. Bakker CJ, Smits HF, Bos C, van der Weide R, Zuiderveld KJ, van Vaals JJ, Hurtak WF, Viergever MA, Mali WP (1998) MR-guided balloon angioplasty: in vitro demonstration of the potential of MRI for guiding, monitoring, and evaluating endovascular interventions. J Magn Reson Imaging 8(1):245-250

27. Glowinski A, Adam G, Bucker A, Neuerburg J, van Vaals JJ, Gunther RW (1997) Catheter visualization using locally induced, actively controlled field inhomogeneities. Magn Reson Med 38(2):253-258

28. Ladd ME, Zimmermann GG, McKinnon GC, von Schulthess GK, Dumoulin CL, Darrow RD, Hofmann E, Debatin JF (1998) Visualization of vascular guidewires using MR tracking. J Magn Reson Imaging 8(1):251-253

29. Leung DA, Debatin JF, Wildermuth S, McKinnon GC, Holtz D, Dumoulin CL, Darrow RD, Hofmann E, von Schulthess GK (1995) Intravascular MR tracking catheter: preliminary experimental evaluation. AJR Am J Roentgenol 164(5):1265-1270

30. Smits HF, Bos C, van der Weide R, Bakker CJ (1998) Endovascular interventional MR: balloon angioplasty in a hemodialysis access flow phantom [corrected]. J Vasc Interv Radiol 9(5):840-845

31. Smits HF, Bos C, van der Weide R, Bakker CJ (1999) Interventional MR: vascular applications. Eur Radiol 9(8):1488-1495

32. Unal O, Korosec FR, Frayne R, Strother CM, Mistretta CA (1998) A rapid 2D time-resolved variable-rate k-space sampling MR technique for passive catheter tracking during endovascular procedures. Magn Reson Med 40(3):356-362

33. van der Weide R, Zuiderveld KJ, Bakker CJ, Hoogenboom T, van Vaals JJ, Viergever MA (1998) Image guidance of endovascular interventions on a clinical MR scanner. IEEE Trans Med Imaging 17(5):779-785

34. Wendt M, Wacker FK (2000) Visualization, tracking, and navigation of instruments for magnetic resonance 
imaging-guided endovascular procedures. Top Magn Reson Imaging 11(3):163-172

35. Hall WA, Liu H, Martin AJ, Pozza CH, Maxwell RE, Truwit CL (2000) Safety, efficacy, and functionality of high-field strength interventional magnetic resonance imaging for neurosurgery. Neurosurgery 46(3):632-641 (discussion 641-632)

36. Martin AJ, Hall WA, Liu H, Pozza CH, Michel E, Casey SO, Maxwell RE, Truwit CL (2000) Brain tumor resection: intraoperative monitoring with high-field-strength MR imaging-initial results. Radiology 215(1):221-228

37. Samset E, Hirschberg H (1999) Neuronavigation in intraoperative MRI. Comput Aided Surg 4(4):200-207

38. Schwartz RB, Hsu L, Wong TZ, Kacher DF, Zamani AA, Black PM, Alexander E III, Stieg PE, Moriarty TM, Martin CA, Kikinis R, Jolesz FA (1999) Intraoperative MR imaging guidance for intracranial neurosurgery: experience with the first 200 cases. Radiology 211(2):477-488

39. Strother CM, Unal O, Frayne R, Turk A, Omary R, Korosec FR, Mistretta CA (2000) Endovascular treatment of experimental canine aneurysms: feasibility with MR imaging guidance. Radiology 215(2):516-519

40. Zhang Q, Wendt M, Aschoff AJ, Zheng L, Lewin JS, Duerk JL (2000) Active MR guidance of interventional devices with target-navigation. Magn Reson Med 44(1):56-65

41. Lakhan SE, Kaplan A, Laird C, Leiter Y (2009) The interventionalism of medicine: interventional radiology, cardiology, and neuroradiology. Int Arch Med 2(1):27

42. Athanasoulis CA (2001) Vascular radiology: looking into the past to learn about the future. Radiology 218(2): 317-322

43. Sousa JE, Costa MA, Tuzcu EM, Yadav JS, Ellis S (2005) New frontiers in interventional cardiology. Circulation 111(5):671-681

44. Peters TM (2006) Image-guidance for surgical procedures. Phys Med Biol 51(14):R505-R540

45. Saeed M, Henk CB, Weber O, Martin A, Wilson M, Shunk K, Saloner D, Higgins CB (2006) Delivery and assessment of endovascular stents to repair aortic coarctation using MR and X-ray imaging. J Magn Reson Imaging 24(2):371-378

46. Modan B, Keinan L, Blumstein T, Sadetzki S (2000) Cancer following cardiac catheterization in childhood. Int J Epidemiol 29(3):424-428

47. Frush DP (2004) Review of radiation issues for computed tomography. Semin Ultrasound CT MR 25(1):17-24

48. Prasad KN, Cole WC, Hasse GM (2004) Health risks of low dose ionizing radiation in humans: a review. Exp Biol Med (Maywood) 229(5):378-382

49. Berrington de Gonzalez A, Darby S (2004) Risk of cancer from diagnostic X-rays: estimates for the UK and 14 other countries. Lancet 363(9406):345-351

50. Brenner D, Elliston C, Hall E, Berdon W (2001) Estimated risks of radiation-induced fatal cancer from pediatric CT. AJR Am J Roentgenol 176(2):289-296

51. Hushek SG, Martin AJ, Steckner M, Bosak E, Debbins J, Kucharzyk W (2008) MR systems for MRI-guided interventions. J Magn Reson Imaging 27(2):253-266

52. Wacker FK, Hillenbrand C, Elgort DR, Zhang S, Duerk JL, Lewin JS (2005) MR imaging-guided percutaneous angioplasty and stent placement in a swine model comparison of open- and closed-bore scanners. Acad Radiol 12(9):1085-1088

53. Weber OM, Schalla S, Martin AJ, Saeed M, Lee R, Shunk KA, Moore P, Higgins CB (2003) Interventional cardiac magnetic resonance imaging. Semin Roentgenol 38(4):352-357

54. Martin AJ, Weber OM, Saeed M, Roberts TP (2003) Steady-state imaging for visualization of endovascular interventions. Magn Reson Med 50(2):434-438

55. Muthurangu V, Taylor A, Andriantsimiavona R, Hegde S, Miquel ME, Tulloh R, Baker E, Hill DL, Razavi RS (2004) Novel method of quantifying pulmonary vascular resistance by use of simultaneous invasive pressure monitoring and phase-contrast magnetic resonance flow. Circulation 110(7):826-834

56. Klemm T, Duda S, Machann J, Seekamp-Rahn K, Schnieder L, Claussen CD, Schick F (2000) MR imaging in the presence of vascular stents: a systematic assessment of artifacts for various stent orientations, sequence types, and field strengths. J Magn Reson Imaging 12(4):606-615

57. Kuehne T, Saeed M, Higgins CB, Gleason K, Krombach GA, Weber OM, Martin AJ, Turner D, Teitel D, Moore P (2003) Endovascular stents in pulmonary valve and artery in swine: feasibility study of MR imaging-guided deployment and postinterventional assessment. Radiology 226(2):475-481

58. Kuehne T, Saeed M, Moore P, Gleason K, Reddy G, Teitel D, Higgins CB (2002) Influence of blood-pool contrast media on MR imaging and flow measurements in the presence of pulmonary arterial stents in swine. Radiology 223(2):439-445

59. Buecker A, Spuentrup E, Ruebben A, Mahnken A, Nguyen TH, Kinzel S, Gunther RW (2004) New metallic MR stents for artifact-free coronary MR angiography: feasibility study in a swine model. Invest Radiol 39(5):250-253

60. Konings MK, Bartels LW, Smits HF, Bakker CJ (2000) Heating around intravascular guidewires by resonating RF waves. J Magn Reson Imaging 12(1):79-85

61. Nitz WR, Oppelt A, Renz W, Manke C, Lenhart M, Link J (2001) On the heating of linear conductive structures as guide wires and catheters in interventional MRI. J Magn Reson Imaging 13(1):105-114

62. Mekle R, Hofmann E, Scheffler K, Bilecen D (2006) A polymer-based MR-compatible guidewire: a study to explore new prospects for interventional peripheral magnetic resonance angiography (ipMRA). J Magn Reson Imaging 23(2):145-155

63. Mekle R, Zenge MO, Ladd ME, Quick HH, Hofmann E, Scheffler K, Bilecen D (2009) Initial in vivo studies with a polymer-based MR-compatible guide wire. J Vasc Interv Radiol 20(10):1384-1389

64. Krueger S, Schmitz S, Weiss S, Wirtz D, Linssen M, Schade H, Kraemer N, Spuentrup E, Krombach G, Buecker A (2008) An MR guidewire based on micropultruded fiber-reinforced material. Magn Reson Med 60(5):1190-1196

65. Karmarkar PV, Kraitchman DL, Izbudak I, Hofmann LV, Amado LC, Fritzges D, Young R, Pittenger M, Bulte JW, 
Atalar E (2004) MR-trackable intramyocardial injection catheter. Magn Reson Med 51(6):1163-1172

66. Saeed M, Lee R, Martin A, Weber O, Krombach GA, Schalla S, Lee M, Saloner D, Higgins CB (2004) Transendocardial delivery of extracellular myocardial markers by using combination X-ray/MR fluoroscopic guidance: feasibility study in dogs. Radiology 231(3):689-696

67. Yang X, Atalar E, Li D, Serfaty JM, Wang D, Kumar A, Cheng L (2001) Magnetic resonance imaging permits in vivo monitoring of catheter-based vascular gene delivery. Circulation 104(14):1588-1590

68. Maes RM, Lewin JS, Duerk JL, Wacker FK (2005) Combined use of the intravascular blood-pool agent, gadomer, and carbon dioxide: a novel type of doublecontrast magnetic resonance angiography (MRA). J Magn Reson Imaging 21(5):645-649

69. Manke C, Nitz WR, Lenhart M, Volk M, Geissler A, Djavidani B, Strotzer M, Kasprzak P, Feuerbach S, Link J (2000) Stent angioplasty of pelvic artery stenosis with MRI control: initial clinical results. Rofo 172(1):92-97

70. Razavi R, Hill DL, Keevil SF, Miquel ME, Muthurangu V, Hegde S, Rhode K, Barnett M, van Vaals J, Hawkes DJ, Baker E (2003) Cardiac catheterisation guided by MRI in children and adults with congenital heart disease. Lancet 362(9399):1877-1882

71. Flask C, Elgort D, Wong E, Shankaranarayanan A, Lewin J, Wendt M, Duerk JL (2001) A method for fast 3D tracking using tuned fiducial markers and a limited projection reconstruction FISP (LPR-FISP) sequence. J Magn Reson Imaging 14(5):617-627

72. Wacker FK, Hillenbrand CM, Duerk JL, Lewin JS (2005) MR-guided endovascular interventions: device visualization, tracking, navigation, clinical applications, and safety aspects. Magn Reson Imaging Clin N Am 13(3): 431-439

73. Saeed M, Martin AJ, Lee RJ, Weber O, Revel D, Saloner D, Higgins CB (2006) MR guidance of targeted injections into border and core of scarred myocardium in pigs. Radiology 240(2):419-426

74. Bock M, Volz S, Zuhlsdorff S, Umathum R, Fink C, Hallscheidt P, Semmler W (2004) MR-guided intravascular procedures: real-time parameter control and automated slice positioning with active tracking coils. J Magn Reson Imaging 19(5):580-589

75. Quick HH, Kuehl H, Kaiser G, Bosk S, Debatin JF, Ladd ME (2002) Inductively coupled stent antennas in MRI. Magn Reson Med 48(5):781-790

76. Hillenbrand CM, Jesberger JA, Wong EY, Zhang S, Chang DT, Wacker FK, Lewin JS, Duerk JL (2006) Toward rapid high resolution in vivo intravascular MRI: evaluation of vessel wall conspicuity in a porcine model using multiple imaging protocols. J Magn Reson Imaging 23(2):135-144

77. Park SM, Kamondetdacha R, Nyenhuis JA (2007) Calculation of MRI-induced heating of an implanted medical lead wire with an electric field transfer function. J Magn Reson Imaging 26(5):1278-1285

78. Kocaturk O, Saikus CE, Guttman MA, Faranesh AZ, Ratnayaka K, Ozturk C, McVeigh ER, Lederman RJ (2009) Whole shaft visibility and mechanical performance for active MR catheters using copper-nitinol braided polymer tubes. J Cardiovasc Magn Reson 11(1):29

79. Rezai AR, Baker KB, Tkach JA, Phillips M, Hrdlicka G, Sharan AD, Nyenhuis J, Ruggieri P, Shellock FG, Henderson J (2005) Is magnetic resonance imaging safe for patients with neurostimulation systems used for deep brain stimulation? Neurosurgery 57(5):1056-1062 (discussion 1056-1062)

80. Nazarian S, Roguin A, Zviman MM, Lardo AC, Dickfeld TL, Calkins H, Weiss RG, Berger RD, Bluemke DA, Halperin HR (2006) Clinical utility and safety of a protocol for noncardiac and cardiac magnetic resonance imaging of patients with permanent pacemakers and implantable-cardioverter defibrillators at 1.5 tesla. Circulation 114(12):1277-1284

81. Sommer T, Naehle CP, Yang A, Zeijlemaker V, Hackenbroch M, Schmiedel A, Meyer C, Strach K, Skowasch D, Vahlhaus C, Litt H, Schild H (2006) Strategy for safe performance of extrathoracic magnetic resonance imaging at 1.5 tesla in the presence of cardiac pacemakers in non-pacemaker-dependent patients: a prospective study with 115 examinations. Circulation 114(12):1285-1292

82. Roguin A, Zviman MM, Meininger GR, Rodrigues ER, Dickfeld TM, Bluemke DA, Lardo A, Berger RD, Calkins H, Halperin HR (2004) Modern pacemaker and implantable cardioverter/defibrillator systems can be magnetic resonance imaging safe: in vitro and in vivo assessment of safety and function at $1.5 \mathrm{~T}$. Circulation 110(5): 475-482

83. Roberts TP, Hassenzahl WV, Hetts SW, Arenson RL (2002) Remote control of catheter tip deflection: an opportunity for interventional MRI. Magn Reson Med 48(6):1091-1095

84. Settecase F, Sussman MS, Wilson MW, Hetts S, Arenson RL, Malba V, Bernhardt AF, Kucharczyk W, Roberts TP (2007) Magnetically-assisted remote control (MARC) steering of endovascular catheters for interventional MRI: a model for deflection and design implications. Med Phys 34(8):3135-3142

85. Demas V, Herberg JL, Malba V, Bernhardt A, Evans L, Harvey C, Chinn SC, Maxwell RS, Reimer J (2007) Portable, low-cost NMR with laser-lathe lithography produced microcoils. J Magn Reson 189(1):121-129

86. Settecase F, Hetts SW, Martin AJ, Roberts TP, Bernhardt AF, Evans L, Malba V, Saeed M, Arenson RL, Kucharzyk W, Wilson MW (2011) RF heating of MRIassisted catheter steering coils for interventional MRI. Acad Radiol. doi: 10.1016/j.acra.2010.09.012

87. Bernhardt A, Wilson MW, Settecase F, Evans L, Malba V, Martin AJ, Saeed M, Roberts TP, Arenson RL, Hetts SW (2011) Steerable catheter microcoils for interventional MRI: reducing resistive heating. Acad Radiol. doi: 10.1016/j.acra.2010.09.010

88. Axel L (1997) Noninvasive measurement of cardiac strain with MRI. Adv Exp Med Biol 430:249-256

89. Osman NF, Kerwin WS, McVeigh ER, Prince JL (1999) Cardiac motion tracking using CINE harmonic phase (HARP) magnetic resonance imaging. Magn Reson Med 42(6): 1048-1060

90. Jacquier A, Higgins CB, Martin AJ, Do L, Saloner D, Saeed M (2007) Injection of adeno-associated viral vector 
encoding vascular endothelial growth factor gene in infarcted swine myocardium: MR measurements of left ventricular function and strain. Radiology 245(1):196-205

91. Aime S, Barge A, Cabella C, Crich SG, Gianolio E (2004) Targeting cells with MR imaging probes based on paramagnetic Gd(III) chelates. Curr Pharm Biotechnol 5(6):509-518

92. Biancone L, Crich SG, Cantaluppi V, Romanazzi GM, Russo S, Scalabrino E, Esposito G, Figliolini F, Beltramo S, Perin PC, Segoloni GP, Aime S, Camussi G (2006) Magnetic resonance imaging of gadolinium-labeled pancreatic islets for experimental transplantation. NMR Biomed

93. Omary RA, Green JD, Fang WS, Viohl I, Finn JP, Li D (2003) Use of internal coils for independent and direct MR imaging-guided endovascular device tracking. J Vasc Interv Radiol 14(2 Pt 1):247-254

94. Omary RA, Green JD, Schirf BE, Li Y, Finn JP, Li D (2003) Real-time magnetic resonance imaging-guided coronary catheterization in swine. Circulation 107(21):2656-2659

95. Saeed M, Weber O, Lee R, Do L, Martin A, Saloner D, Ursell P, Robert P, Corot C, Higgins CB (2006) Discrimination of myocardial acute and chronic (scar) infarctions on delayed contrast enhanced magnetic resonance imaging with intravascular magnetic resonance contrast media. J Am Coll Cardiol 48(10):1961-1968

96. Kraitchman DL, Tatsumi M, Gilson WD, Ishimori T, Kedziorek D, Walczak P, Segars WP, Chen HH, Fritzges D, Izbudak I, Young RG, Marcelino M, Pittenger MF, Solaiyappan M, Boston RC, Tsui BM, Wahl RL, Bulte JW (2005) Dynamic imaging of allogeneic mesenchymal stem cells trafficking to myocardial infarction. Circulation 112(10):1451-1461

97. Hill JM, Dick AJ, Raman VK, Thompson RB, Yu ZX, Hinds KA, Pessanha BS, Guttman MA, Varney TR, Martin BJ, Dunbar CE, McVeigh ER, Lederman RJ (2003) Serial cardiac magnetic resonance imaging of injected mesenchymal stem cells. Circulation 108(8):1009-1014

98. Arai T, Kofidis T, Bulte JW, de Bruin J, Venook RD, Berry GJ, McConnell MV, Quertermous T, Robbins RC, Yang PC (2006) Dual in vivo magnetic resonance evaluation of magnetically labeled mouse embryonic stem cells and cardiac function at $1.5 \mathrm{t}$. Magn Reson Med 55(1):203-209

99. Sadowski EA, Bennett LK, Chan MR, Wentland AL, Garrett AL, Garrett RW, Djamali A (2007) Nephrogenic systemic fibrosis: risk factors and incidence estimation. Radiology 243(1):148-157

100. Bongartz G, Mayr M, Bilecen D (2008) Magnetic resonance angiography (MRA) in renally impaired patients: when and how. Eur J Radiol 66(2):213-219

101. Busse RF, Riederer SJ (2001) Steady-state preparation for spoiled gradient echo imaging. Magn Reson Med 45(4): 653-661

102. Elgort DR, Duerk JL (2005) A review of technical advances in interventional magnetic resonance imaging. Acad Radiol 12(9):1089-1099

103. Duerk JL, Lewin JS, Wendt M, Petersilge C (1998) Remember true FISP? A high SNR, near 1-second imaging method for T2-like contrast in interventional MRI at.2 T. J Magn Reson Imaging 8(1):203-208
104. Bock M, Muller S, Zuehlsdorff S, Speier P, Fink C, Hallscheidt P, Umathum R, Semmler W (2006) Active catheter tracking using parallel MRI and real-time image reconstruction. Magn Reson Med 55(6):1454-1459

105. Peters DC, Lederman RJ, Dick AJ, Raman VK, Guttman MA, Derbyshire JA, McVeigh ER (2003) Undersampled projection reconstruction for active catheter imaging with adaptable temporal resolution and catheter-only views. Magn Reson Med 49(2):216-222

106. Spielman DM, Pauly JM, Meyer CH (1995) Magnetic resonance fluoroscopy using spirals with variable sampling densities. Magn Reson Med 34(3):388-394

107. Rasche V, de Boer RW, Holz D, Proksa R (1995) Continuous radial data acquisition for dynamic MRI. Magn Reson Med 34(5):754-761

108. Rasche V, Holz D, Kohler J, Proksa R, Roschmann P (1997) Catheter tracking using continuous radial MRI. Magn Reson Med 37(6):963-968

109. Pruessmann KP, Weiger M, Scheidegger MB, Boesiger $P$ (1999) SENSE: sensitivity encoding for fast MRI. Magn Reson Med 42(5):952-962

110. Niendorf T, Sodickson DK (2006) Parallel imaging in cardiovascular MRI: methods and applications. NMR Biomed 19(3):325-341

111. Kyriakos WE, Hoge WS, Mitsouras D (2006) Generalized encoding through the use of selective excitation in accelerated parallel MRI. NMR Biomed 19(3):379-392

112. Carlsson M, Osman NF, Ursell PC, Martin AJ, Saeed M (2008) Quantitative MR measurements of regional and global left ventricular function and strain after intramyocardial transfer of VM202 into infarcted swine myocardium. Am J Physiol Heart Circ Physiol 295(2):H522H532

113. Saeed M, Martin A, Ursell P, Do L, Bucknor M, Higgins CB, Saloner D (2008) MR assessment of myocardial perfusion, viability and function after intramyocardial transfer of VM202, a new plasmid human hepatocyte growth factor in ischemic swine myocardium. Radiology 249(1):107-118

114. Dicks D, Saloner D, Martin A, Ursell P, Carlsson M, Saeed M (2010) Cardiovascular magnetic resonance imaging for percutaneous transendocardial delivery and three dimensional left ventricular strain assessment of VEGF gene therapy in occlusive infarction. Int J Cardiol 143(3):255-263

115. Carlsson M, Jablonowski R, Martin A, Ursell P, Saeed M (2011) Impaired regional perfusion after coronary microembolization predicts long-term detrimental effects on regional left ventricular function. Scand Cardiovasc J (in press)

116. Dicks DL, Carlsson M, Heiberg E, Martin A, Saloner D, Arheden H, Saeed M (2009) Persistent decline in longitudinal and radial strain after coronary microembolization detected on velocity encoded phase contrast magnetic resonance imaging. J Magn Reson Imaging 30(1):69-76

117. Bergvall E, Cain P, Arheden H, Sparr G (2006) A fast and highly automated approach to myocardial motion analysis using phase contrast magnetic resonance imaging. J Magn Reson Imaging 23(5):652-661

118. Saeed M, Martin AJ, Saloner D, Do L, Wilson M (2010) Noninvasive MR characterization of structural and 
functional components of reperfused infarct. Acta Radiol 51(10):1093-1102

119. Kramer CM, Budoff MJ, Fayad ZA, Ferrari VA, Goldman C, Lesser JR, Martin ET, Rajagopalan S, Reilly JP, Rodgers GP, Wechsler L (2007) ACCF/AHA 2007 clinical competence statement on vascular imaging with computed tomography and magnetic resonance. Vasc Med 12(4):359-378

120. Choudhury RP, Fuster V, Fayad ZA (2004) Molecular, cellular and functional imaging of atherothrombosis. Nat Rev Drug Discov 3(11):913-925

121. Manke C, Nitz WR, Djavidani B, Strotzer M, Lenhart M, Volk M, Feuerbach S, Link J (2001) MR imaging-guided stent placement in iliac arterial stenoses: a feasibility study. Radiology 219(2):527-534

122. Paetzel C, Zorger N, Bachthaler M, Hamer OW, Stehr A, Feuerbach S, Lenhart M, Volk M, Herold T, Kasprzak P, Nitz WR (2005) Magnetic resonance-guided percutaneous angioplasty of femoral and popliteal artery stenoses using real-time imaging and intra-arterial contrastenhanced magnetic resonance angiography. Invest Radiol 40(5):257-262

123. Paetzel C, Zorger N, Bachthaler M, Volk M, Seitz J, Herold T, Feuerbach S, Lenhart M, Nitz WR (2004) Feasibility of MR-guided angioplasty of femoral artery stenoses using real-time imaging and intraarterial contrast-enhanced MR angiography. Rofo 176(9):12321236

124. Omary RA, Frayne R, Unal O, Warner T, Korosec FR, Mistretta CA, Strother CM, Grist TM (2000) MR-guided angioplasty of renal artery stenosis in a pig model: a feasibility study. J Vasc Interv Radiol 11(3):373-381

125. Raval AN, Telep JD, Guttman MA, Ozturk C, Jones M, Thompson RB, Wright VJ, Schenke WH, DeSilva R, Aviles RJ, Raman VK, Slack MC, Lederman RJ (2005) Real-time magnetic resonance imaging-guided stenting of aortic coarctation with commercially available catheter devices in swine. Circulation 112(5):699-706

126. Spuentrup E, Ruebben A, Schaeffter T, Manning WJ, Gunther RW, Buecker A (2002) Magnetic resonanceguided coronary artery stent placement in a swine model. Circulation 105(7):874-879

127. Buecker A, Neuerburg JM, Adam GB, Glowinski A, Schaeffter T, Rasche V, van Vaals JJ, Molgaard-Nielsen A, Guenther RW (2000) Real-time MR fluoroscopy for MR-guided iliac artery stent placement. J Magn Reson Imaging 12(4):616-622

128. Dion YM, Ben El Kadi H, Boudoux C, Gourdon J, Chakfe N, Traore A, Moisan C (2000) Endovascular procedures under near-real-time magnetic resonance imaging guidance: an experimental feasibility study. J Vasc Surg 32(5):1006-1014

129. Hamer OW, Borisch I, Paetzel C, Nitz WR, Seitz J, Feuerbach S, Zorger N (2006) In vitro evaluation of stent patency and in-stent stenoses in 10 metallic stents using MR angiography. Br J Radiol 79(944):636-643

130. Boll DT, Lewin JS, Duerk JL, Smith D, Subramanyan K, Merkle EM (2004) Assessment of automatic vessel tracking techniques in preoperative planning of transluminal aortic stent graft implantation. J Comput Assist Tomogr 28(2):278-285
131. Raman VK, Karmarkar PV, Guttman MA, Dick AJ, Peters DC, Ozturk C, Pessanha BS, Thompson RB, Raval AN, DeSilva R, Aviles RJ, Atalar E, McVeigh ER, Lederman RJ (2005) Real-time magnetic resonance-guided endovascular repair of experimental abdominal aortic aneurysm in swine. J Am Coll Cardiol 45(12):2069-2077

132. Mahnken AH, Chalabi K, Jalali F, Gunther RW, Buecker A (2004) Magnetic resonance-guided placement of aortic stents grafts: feasibility with real-time magnetic resonance fluoroscopy. J Vasc Interv Radiol $15(2 \mathrm{Pt}$ 1):189-195

133. Kos S, Huegli R, Hofmann E, Quick HH, Kuehl H, Aker S, Kaiser GM, Borm PJ, Jacob AL, Bilecen D (2009) First magnetic resonance imaging-guided aortic stenting and cava filter placement using a polyetheretherketone-based magnetic resonance imaging-compatible guidewire in swine: proof of concept. Cardiovasc Intervent Radiol 32(3):514-521

134. Bartels LW, Smits HF, Bakker CJ, Viergever MA (2001) MR imaging of vascular stents: effects of susceptibility, flow, and radiofrequency eddy currents. $J$ Vasc Interv Radiol 12(3):365-371

135. Bucker A, Neuerburg JM, Adam GB, Glowinski A, Schaeffter T, Rasche V, van Vaals JJ, Gunther RW (2001) Real-time MR Guidance for inferior vena cava filter placement in an animal model. J Vasc Interv Radiol 12(6):753-756

136. Kuehne T, Saeed M, Reddy G, Akbari H, Gleason K, Turner D, Teitel D, Moore P, Higgins CB (2001) Sequential magnetic resonance monitoring of pulmonary flow with endovascular stents placed across the pulmonary valve in growing Swine. Circulation 104(19):23632368

137. Kuehne T, Yilmaz S, Steendijk P, Moore P, Groenink M, Saaed M, Weber O, Higgins CB, Ewert P, Fleck E, Nagel E, Schulze-Neick I, Lange P (2004) Magnetic resonance imaging analysis of right ventricular pressure-volume loops: in vivo validation and clinical application in patients with pulmonary hypertension. Circulation 110(14):2010-2016

138. Krueger JJ, Ewert P, Yilmaz S, Gelernter D, Peters B, Pietzner K, Bornstedt A, Schnackenburg B, Abdul-Khaliq H, Fleck E, Nagel E, Berger F, Kuehne T (2006) Magnetic resonance imaging-guided balloon angioplasty of coarctation of the aorta: a pilot study. Circulation 113(8):1093-1100

139. Kuehne T, Yilmaz S, Meinus C, Moore P, Saeed M, Weber O, Higgins CB, Blank T, Elsaesser E, Schnackenburg B, Ewert P, Lange PE, Nagel E (2004) Magnetic resonance imaging-guided transcatheter implantation of a prosthetic valve in aortic valve position: feasibility study in swine. J Am Coll Cardiol 44(11):2247-2249

140. McVeigh ER, Guttman MA, Lederman RJ, Li M, Kocaturk O, Hunt T, Kozlov S, Horvath KA (2006) Real-time interactive MRI-guided cardiac surgery: aortic valve replacement using a direct apical approach. Magn Reson Med 56(5):958-964

141. Rickers C, Jerosch-Herold M, Hu X, Murthy N, Wang X, Kong H, Seethamraju RT, Weil J, Wilke NM (2003) Magnetic resonance image-guided transcatheter closure of atrial septal defects. Circulation 107(1):132-138 
142. Shellock FG, Valencerina S (2005) Septal repair implants: evaluation of magnetic resonance imaging safety at 3 T. Magn Reson Imaging 23(10):1021-1025

143. Babu-Narayan SV, Goktekin O, Moon JC, Broberg CS, Pantely GA, Pennell DJ, Gatzoulis MA, Kilner PJ (2005) Late gadolinium enhancement cardiovascular magnetic resonance of the systemic right ventricle in adults with previous atrial redirection surgery for transposition of the great arteries. Circulation 111(16):2091-2098

144. Nazarian S, Bluemke DA, Lardo AC, Zviman MM, Watkins SP, Dickfeld TL, Meininger GR, Roguin A, Calkins H, Tomaselli GF, Weiss RG, Berger RD, Lima JA, Halperin HR (2005) Magnetic resonance assessment of the substrate for inducible ventricular tachycardia in nonischemic cardiomyopathy. Circulation 112(18):2821-2825

145. Carrillo A, Duerk JL, Lewin JS, Wilson DL (2000) Semiautomatic 3-D image registration as applied to interventional MRI liver cancer treatment. IEEE Trans Med Imaging 19(3):175-185

146. de Zwart JA, Vimeux FC, Palussiere J, Salomir R, Quesson B, Delalande C, Moonen CT (2001) On-line correction and visualization of motion during MRI-controlled hyperthermia. Magn Reson Med 45(1):128-137

147. Quesson B, de Zwart JA, Moonen CT (2000) Magnetic resonance temperature imaging for guidance of thermotherapy. J Magn Reson Imaging 12(4):525-533

148. Salomir R, Vimeux FC, de Zwart JA, Grenier N, Moonen CT (2000) Hyperthermia by MR-guided focused ultrasound: accurate temperature control based on fast MRI and a physical model of local energy deposition and heat conduction. Magn Reson Med 43(3):342-347

149. Sinha S, Oshiro T, Sinha U, Lufkin R (1997) Phase imaging on a.2-T MR scanner: application to temperature monitoring during ablation procedures. J Magn Reson Imaging 7(5):918-928

150. Vogl TJ, Mack MG, Muller PK, Straub R, Engelmann K, Eichler K (1999) Interventional MR: interstitial therapy. Eur Radiol 9(8):1479-1487

151. Peters DC, Wylie JV, Hauser TH, Kissinger KV, Botnar RM, Essebag V, Josephson ME, Manning WJ (2007) Detection of pulmonary vein and left atrial scar after catheter ablation with three-dimensional navigator-gated delayed enhancement MR imaging: initial experience. Radiology 243(3):690-695

152. Reddy VY, Schmidt EJ, Holmvang G, Fung M (2008) Arrhythmia recurrence after atrial fibrillation ablation: can magnetic resonance imaging identify gaps in atrial ablation lines? J Cardiovasc Electrophysiol 19(4):434-437

153. McGann CJ, Kholmovski EG, Oakes RS, Blauer JJ, Daccarett M, Segerson N, Airey KJ, Akoum N, Fish E, Badger TJ, DiBella EV, Parker D, MacLeod RS, Marrouche NF (2008) New magnetic resonance imagingbased method for defining the extent of left atrial wall injury after the ablation of atrial fibrillation. J Am Coll Cardiol 52(15):1263-1271

154. Bello D, Fieno DS, Kim RJ, Pereles FS, Passman R, Song G, Kadish AH, Goldberger JJ (2005) Infarct morphology identifies patients with substrate for sustained ventricular tachycardia. J Am Coll Cardiol 45(7):1104-1108

155. Schmidt A, Azevedo CF, Cheng A, Gupta SN, Bluemke DA, Foo TK, Gerstenblith G, Weiss RG, Marban E,
Tomaselli GF, Lima JA, Wu KC (2007) Infarct tissue heterogeneity by magnetic resonance imaging identifies enhanced cardiac arrhythmia susceptibility in patients with left ventricular dysfunction. Circulation 115(15):20062014

156. Dong J, Dickfeld T, Dalal D, Cheema A, Vasamreddy CR, Henrikson CA, Marine JE, Halperin HR, Berger RD, Lima JA, Bluemke DA, Calkins H (2006) Initial experience in the use of integrated electroanatomic mapping with three-dimensional MR/CT images to guide catheter ablation of atrial fibrillation. J Cardiovasc Electrophysiol 17(5):459-466

157. Mansour M, Refaat M, Heist EK, Mela T, Cury R, Holmvang G, Ruskin JN (2006) Three-dimensional anatomy of the left atrium by magnetic resonance angiography: implications for catheter ablation for atrial fibrillation. J Cardiovasc Electrophysiol 17(7):719-723

158. Kenigsberg DN, Lee BP, Grizzard JD, Ellenbogen KA, Wood MA (2007) Accuracy of intracardiac echocardiography for assessing the esophageal course along the posterior left atrium: a comparison to magnetic resonance imaging. J Cardiovasc Electrophysiol 18(2):169-173

159. Arepally A, Karmarkar PV, Weiss C, Rodriguez ER, Lederman RJ, Atalar E (2005) Magnetic resonance image-guided trans-septal puncture in a swine heart. J Magn Reson Imaging 21(4):463-467

160. Raval AN, Karmarkar PV, Guttman MA, Ozturk C, Desilva R, Aviles RJ, Wright VJ, Schenke WH, Atalar E, McVeigh ER, Lederman RJ (2006) Real-time MRI guided atrial septal puncture and balloon septostomy in swine. Catheter Cardiovasc Interv 67(4):637-643

161. Schalla S, Saeed M, Higgins CB, Martin A, Weber O, Moore P (2003) Magnetic resonance-guided cardiac catheterization in a swine model of atrial septal defect. Circulation 108(15):1865-1870

162. Omeish A, Hijazi ZM (2001) Transcatheter closure of atrial septal defects in children \& adults using the Amplatzer Septal Occluder. J Interv Cardiol 14(1):37-44

163. Kersting-Sommerhoff BA, Diethelm L, Stanger P, Dery R, Higashino SM, Higgins SS, Higgins CB (1990) Evaluation of complex congenital ventricular anomalies with magnetic resonance imaging. Am Heart J 120(1):133-142

164. Buecker A, Adam GB, Neuerburg JM, Kinzel S, Glowinski A, Schaeffter T, Rasche V, van Vaals JJ, Guenther RW (2002) Simultaneous real-time visualization of the catheter tip and vascular anatomy for MR-guided PTA of iliac arteries in an animal model. J Magn Reson Imaging 16(2):201-208

165. Buecker A, Spuentrup E, Grabitz R, Freudenthal F, Muehler EG, Schaeffter T, van Vaals JJ, Gunther RW (2002) Magnetic resonance-guided placement of atrial septal closure device in animal model of patent foramen ovale. Circulation 106(4):511-515

166. Schalla S, Saeed M, Higgins CB, Weber O, Martin A, Moore P (2005) Balloon sizing and transcatheter closure of acute atrial septal defects guided by magnetic resonance fluoroscopy: assessment and validation in a large animal model. J Magn Reson Imaging 21(3):204-211

167. Kuehne T, Yilmaz S, Schulze-Neick I, Wellnhofer E, Ewert P, Nagel E, Lange P (2005) Magnetic resonance imaging guided catheterisation for assessment of 
pulmonary vascular resistance: in vivo validation and clinical application in patients with pulmonary hypertension. Heart 91(8):1064-1069

168. Arepally A, Karmarkar PV, Weiss C, Atalar E (2006) Percutaneous MR imaging-guided transvascular access of mesenteric venous system: study in swine model. Radiology 238(1):113-118

169. Dick AJ, Raman VK, Raval AN, Guttman MA, Thompson RB, Ozturk C, Peters DC, Stine AM, Wright VJ, Schenke WH, Lederman RJ (2005) Invasive human magnetic resonance imaging: feasibility during revascularization in a combined XMR suite. Catheter Cardiovasc Interv 64(3):265-274

170. Stamm C, Kleine HD, Choi YH, Dunkelmann S, Lauffs JA, Lorenzen B, David A, Liebold A, Nienaber C, Zurakowski D, Freund M, Steinhoff G (2007) Intramyocardial delivery of CD133+ bone marrow cells and coronary artery bypass grafting for chronic ischemic heart disease: safety and efficacy studies. J Thorac Cardiovasc Surg 133(3):717-725

171. Allen KB, Dowling RD, Fudge TL, Schoettle GP, Selinger SL, Gangahar DM, Angell WW, Petracek MR, Shaar CJ, O'Neill WW (1999) Comparison of transmyocardial revascularization with medical therapy in patients with refractory angina. $\mathrm{N}$ Engl $\mathrm{J}$ Med 341(14):1029-1036

172. Kleiman NS, Patel NC, Allen KB, Simons M, Yla-Herttuala S, Griffin E, Dzau VJ (2003) Evolving revascularization approaches for myocardial ischemia. Am J Cardiol 92(9B):9N-17N

173. Laham RJ, Sellke FW, Edelman ER, Pearlman JD, Ware JA, Brown DL, Gold JP, Simons M (1999) Local perivascular delivery of basic fibroblast growth factor in patients undergoing coronary bypass surgery: results of a phase I randomized, double-blind, placebo-controlled trial. Circulation 100(18):1865-1871

174. Ruel M, Laham RJ, Parker JA, Post MJ, Ware JA, Simons M, Sellke FW (2002) Long-term effects of surgical angiogenic therapy with fibroblast growth factor 2 protein. J Thorac Cardiovasc Surg 124(1):28-34

175. Simons M, Bonow RO, Chronos NA, Cohen DJ, Giordano FJ, Hammond HK, Laham RJ, Li W, Pike M, Sellke FW, Stegmann TJ, Udelson JE, Rosengart TK (2000) Clinical trials in coronary angiogenesis: issues, problems, consensus: an expert panel summary. Circulation 102(11):E73-E86

176. Menasche P, Alfieri O, Janssens S, McKenna W, Reichenspurner H, Trinquart L, Vilquin JT, Marolleau JP, Seymour B, Larghero J, Lake S, Chatellier G, Solomon S, Desnos M, Hagege AA (2008) The myoblast autologous grafting in ischemic cardiomyopathy (MAGIC) trial: first randomized placebo-controlled study of myoblast transplantation. Circulation 117(9):1189-1200

177. Freyman T, Polin G, Osman H, Crary J, Lu M, Cheng L, Palasis M, Wilensky RL (2006) A quantitative, randomized study evaluating three methods of mesenchymal stem cell delivery following myocardial infarction. Eur Heart J 27(9):1114-1122

178. Saito T, Kuang JQ, Lin CC, Chiu RC (2003) Transcoronary implantation of bone marrow stromal cells ameliorates cardiac function after myocardial infarction. J Thorac Cardiovasc Surg 126(1):114-123
179. Assmus B, Honold J, Schachinger V, Britten MB, Fischer-Rasokat U, Lehmann R, Teupe C, Pistorius K, Martin H, Abolmaali ND, Tonn T, Dimmeler S, Zeiher AM (2006) Transcoronary transplantation of progenitor cells after myocardial infarction. $N$ Engl $\mathrm{J}$ Med 355(12):1222-1232

180. Narazaki G, Uosaki H, Teranishi M, Okita K, Kim B, Matsuoka S, Yamanaka S, Yamashita JK (2008) Directed and systematic differentiation of cardiovascular cells from mouse induced pluripotent stem cells. Circulation 118(5):498-506

181. Hou D, Youssef EA, Brinton TJ, Zhang P, Rogers P, Price ET, Yeung AC, Johnstone BH, Yock PG, March KL (2005) Radiolabeled cell distribution after intramyocardial, intracoronary, and interstitial retrograde coronary venous delivery: implications for current clinical trials. Circulation 112(9 Suppl):I150-I156

182. Klein HM, Ghodsizad A, Marktanner R, Poll L, Voelkel T, Mohammad Hasani MR, Piechaczek C, Feifel N, Stockschlaeder M, Burchardt ER, Kar BJ, Gregoric I, Gams E (2007) Intramyocardial implantation of CD133+ stem cells improved cardiac function without bypass surgery. Heart Surg Forum 10(1):E66-E69

183. Simonetti O, Lucarini G, Brancorsini D, Nita P, Bernardini ML, Biagini G, Offidani A (2002) Immunohistochemical expression of vascular endothelial growth factor, matrix metalloproteinase 2 , and matrix metalloproteinase 9 in cutaneous melanocytic lesions. Cancer 95(9):1963-1970

184. Pearlman JD, Laham RJ, Simons M (2000) Coronary angiogenesis: detection in vivo with MR imaging sensitive to collateral neocirculation-preliminary study in pigs. Radiology 214(3):801-807

185. Post MJ, Sato K, Murakami M, Bao J, Tirziu D, Pearlman JD, Simons M (2006) Adenoviral PR39 improves blood flow and myocardial function in a pig model of chronic myocardial ischemia by enhancing collateral formation. Am J Physiol Regul Integr Comp Physiol 290(3):R494R500

186. Liu Y, Sun L, Huan Y, Zhao H, Deng J (2006) Effects of basic fibroblast growth factor microspheres on angiogenesis in ischemic myocardium and cardiac function: analysis with dobutamine cardiovascular magnetic resonance tagging. Eur J Cardiothorac Surg 30(1):103-107

187. Dick AJ, Guttman MA, Raman VK, Peters DC, Pessanha BS, Hill JM, Smith S, Scott G, McVeigh ER, Lederman RJ (2003) Magnetic resonance fluoroscopy allows targeted delivery of mesenchymal stem cells to infarct borders in swine. Circulation 108(23):2899-2904

188. Dick AJ, Lederman RJ (2005) MRI-guided myocardial cell therapy. Int J Cardiovasc Interv 7(4):165-170

189. Kraitchman DL, Heldman AW, Atalar E, Amado LC, Martin BJ, Pittenger MF, Hare JM, Bulte JW (2003) In vivo magnetic resonance imaging of mesenchymal stem cells in myocardial infarction. Circulation 107(18):2290-2293

190. Ebert SN, Taylor DG, Nguyen HL, Kodack DP, Beyers RJ, Xu Y, Yang Z, French BA (2007) Noninvasive tracking of cardiac embryonic stem cells in vivo using magnetic resonance imaging techniques. Stem Cells 25(11):2936-2944 
191. Budde MD, Frank JA (2009) Magnetic tagging of therapeutic cells for MRI. J Nucl Med 50(2):171-174

192. Arbab AS, Yocum GT, Rad AM, Khakoo AY, Fellowes V, Read EJ, Frank JA (2005) Labeling of cells with ferumoxides-protamine sulfate complexes does not inhibit function or differentiation capacity of hematopoietic or mesenchymal stem cells. NMR Biomed 18(8):553-559

193. Himes N, Min JY, Lee R, Brown C, Shea J, Huang X, Xiao YF, Morgan JP, Burstein D, Oettgen P (2004) In vivo MRI of embryonic stem cells in a mouse model of myocardial infarction. Magn Reson Med 52(5):1214-1219

194. Cahill KS, Germain S, Byrne BJ, Walter GA (2004) Noninvasive analysis of myoblast transplants in rodent cardiac muscle. Int J Cardiovasc Imaging 20(6):593-598

195. Amado LC, Saliaris AP, Schuleri KH, St John M, Xie JS, Cattaneo S, Durand DJ, Fitton T, Kuang JQ, Stewart G, Lehrke S, Baumgartner WW, Martin BJ, Heldman AW, Hare JM (2005) Cardiac repair with intramyocardial injection of allogeneic mesenchymal stem cells after myocardial infarction. Proc Natl Acad Sci USA 102(32):11474-11479

196. Moelker AD, Baks T, van den Bos EJ, van Geuns RJ, de Feyter PJ, Duncker DJ, van der Giessen WJ (2006) Reduction in infarct size, but no functional improvement after bone marrow cell administration in a porcine model of reperfused myocardial infarction. Eur Heart $\mathrm{J}$ 27(24):3057-3064

197. Grauss RW, van Tuyn J, Steendijk P, Winter EM, Pijnappels DA, Hogers B, Gittenberger-De Groot AC, van der Geest R, van der Laarse A, de Vries AA, Schalij MJ, Atsma DE (2008) Forced myocardin expression enhances the therapeutic effect of human mesenchymal stem cells after transplantation in ischemic mouse hearts. Stem Cells 26(4):1083-1093

198. Hashemi SM, Ghods S, Kolodgie FD, Parcham-Azad K, Keane M, Hamamdzic D, Young R, Rippy MK, Virmani R, Litt H, Wilensky RL (2008) A placebo controlled, dose-ranging, safety study of allogenic mesenchymal stem cells injected by endomyocardial delivery after an acute myocardial infarction. Eur Heart J 29(2):251-259

199. Ziebart T, Yoon CH, Trepels T, Wietelmann A, Braun T, Kiessling F, Stein S, Grez M, Ihling C, Muhly-Reinholz M, Carmona G, Urbich C, Zeiher AM, Dimmeler S (2008) Sustained persistence of transplanted proangiogenic cells contributes to neovascularization and cardiac function after ischemia. Circ Res 103(11):1327-1334

200. Amado LC, Schuleri KH, Saliaris AP, Boyle AJ, Helm R, Oskouei B, Centola M, Eneboe V, Young R, Lima JA, Lardo AC, Heldman AW, Hare JM (2006) Multimodality noninvasive imaging demonstrates in vivo cardiac regeneration after mesenchymal stem cell therapy. J Am Coll Cardiol 48(10):2116-2124

201. Bartunek J, Vanderheyden M, Vandekerckhove B, Mansour S, De Bruyne B, De Bondt P, Van Haute I, Lootens N, Heyndrickx G, Wijns W (2005) Intracoronary injection of CD133-positive enriched bone marrow progenitor cells promotes cardiac recovery after recent myocardial infarction: feasibility and safety. Circulation 112(9 Suppl):I178-I183

202. Janssens S, Dubois C, Bogaert J, Theunissen K, Deroose C, Desmet W, Kalantzi M, Herbots L, Sinnaeve P, Dens J,
Maertens J, Rademakers F, Dymarkowski S, Gheysens O, Van Cleemput J, Bormans G, Nuyts J, Belmans A, Mortelmans L, Boogaerts M, Van de Werf F (2006) Autologous bone marrow-derived stem-cell transfer in patients with ST-segment elevation myocardial infarction: double-blind, randomised controlled trial. Lancet 367(9505):113-121

203. Wollert KC, Meyer GP, Lotz J, Ringes-Lichtenberg S, Lippolt P, Breidenbach C, Fichtner S, Korte T, Hornig B, Messinger D, Arseniev L, Hertenstein B, Ganser A, Drexler H (2004) Intracoronary autologous bone-marrow cell transfer after myocardial infarction: the BOOST randomised controlled clinical trial. Lancet 364(9429): 141-148

204. Schachinger V, Erbs S, Elsasser A, Haberbosch W, Hambrecht R, Holschermann H, Yu J, Corti R, Mathey DG, Hamm CW, Suselbeck T, Assmus B, Tonn T, Dimmeler S, Zeiher AM (2006) Intracoronary bone marrow-derived progenitor cells in acute myocardial infarction. N Engl J Med 355(12):1210-1221

205. Schachinger V, Erbs S, Elsasser A, Haberbosch W, Hambrecht R, Holschermann H, Yu J, Corti R, Mathey DG, Hamm CW, Suselbeck T, Werner N, Haase J, Neuzner J, Germing A, Mark B, Assmus B, Tonn T, Dimmeler S, Zeiher AM (2006) Improved clinical outcome after intracoronary administration of bone-marrowderived progenitor cells in acute myocardial infarction: final 1-year results of the REPAIR-AMI trial. Eur Heart J 27(23):2775-2783

206. Dill T, Schachinger V, Rolf A, Mollmann S, Thiele H, Tillmanns H, Assmus B, Dimmeler S, Zeiher AM, Hamm C (2009) Intracoronary administration of bone marrowderived progenitor cells improves left ventricular function in patients at risk for adverse remodeling after acute STsegment elevation myocardial infarction: results of the reinfusion of enriched progenitor cells and infarct remodeling in acute myocardial infarction study (REPAIR-AMI) cardiac magnetic resonance imaging substudy. Am Heart J 157(3):541-547

207. Dimmeler S, Zeiher AM (2009) Cell therapy of acute myocardial infarction: open questions. Cardiology 113(3):155-160

208. Schaefer A, Zwadlo C, Fuchs M, Meyer GP, Lippolt P, Wollert KC, Drexler H (2010) Long-term effects of intracoronary bone marrow cell transfer on diastolic function in patients after acute myocardial infarction: 5-years results from the randomized-controlled BOOST trial-an echocardiographic study. Eur J Echocardiogr 11(2):165-171

209. Yousef M, Schannwell CM, Kostering M, Zeus T, Brehm M, Strauer BE (2009) The balance study: clinical benefit and long-term outcome after intracoronary autologous bone marrow cell transplantation in patients with acute myocardial infarction. J Am Coll Cardiol 53(24):2262-2269

210. Vulliet PR, Greeley M, Halloran SM, MacDonald KA, Kittleson MD (2004) Intra-coronary arterial injection of mesenchymal stromal cells and microinfarction in dogs. Lancet 363(9411):783-784

211. Tossios P, Krausgrill B, Schmidt M, Fischer T, Halbach M, Fries JW, Fahnenstich S, Frommolt P, Heppelmann I, Schmidt A, Schomacker K, Fischer JH, Bloch W, Mehlhorn U, Schwinger RH, Muller-Ehmsen J (2008) Role of 
balloon occlusion for mononuclear bone marrow cell deposition after intracoronary injection in pigs with reperfused myocardial infarction. Eur Heart J 29(15): 1911-1921

212. Hirsch A, Nijveldt R, van der Vleuten PA, Tio RA, van der Giessen WJ, Marques KM, Doevendans PA, Waltenberger J, Ten Berg JM, Aengevaeren WR, Biemond BJ, Tijssen JG, van Rossum AC, Piek JJ, Zijlstra F (2008) Intracoronary infusion of autologous mononuclear bone marrow cells in patients with acute myocardial infarction treated with primary PCI: pilot study of the multicenter HEBE trial. Catheter Cardiovasc Interv 71(3):273-281

213. Hofmann M, Wollert KC, Meyer GP, Menke A, Arseniev L, Hertenstein B, Ganser A, Knapp WH, Drexler H (2005) Monitoring of bone marrow cell homing into the infarcted human myocardium. Circulation 111(17):2198-2202

214. Ripa RS, Jorgensen E, Wang Y, Thune JJ, Nilsson JC, Sondergaard L, Johnsen HE, Kober L, Grande P, Kastrup J (2006) Stem cell mobilization induced by subcutaneous granulocyte-colony stimulating factor to improve cardiac regeneration after acute ST-elevation myocardial infarction: result of the double-blind, randomized, placebocontrolled stem cells in myocardial infarction (STEMMI) trial. Circulation 113(16):1983-1992

215. Zohlnhofer D, Ott I, Mehilli J, Schomig K, Michalk F, Ibrahim T, Meisetschlager G, von Wedel J, Bollwein H, Seyfarth M, Dirschinger J, Schmitt C, Schwaiger M, Kastrati A, Schomig A (2006) Stem cell mobilization by granulocyte colony-stimulating factor in patients with acute myocardial infarction: a randomized controlled trial. Jama 295(9):1003-1010

216. Fernandez-Aviles F, San Roman JA, Garcia-Frade J, Fernandez ME, Penarrubia MJ, de la Fuente L, GomezBueno M, Cantalapiedra A, Fernandez J, Gutierrez O, Sanchez PL, Hernandez C, Sanz R, Garcia-Sancho J, Sanchez A (2004) Experimental and clinical regenerative capability of human bone marrow cells after myocardial infarction. Circ Res 95(7):742-748

217. Schachinger V, Assmus B, Britten MB, Honold J, Lehmann R, Teupe C, Abolmaali ND, Vogl TJ, Hofmann WK, Martin H, Dimmeler S, Zeiher AM (2004) Transplantation of progenitor cells and regeneration enhancement in acute myocardial infarction: final one-year results of the TOPCARE-AMI trial. J Am Coll Cardiol 44(8): 1690-1699
218. Chen SL, Fang WW, Ye F, Liu YH, Qian J, Shan SJ, Zhang JJ, Chunhua RZ, Liao LM, Lin S, Sun JP (2004) Effect on left ventricular function of intracoronary transplantation of autologous bone marrow mesenchymal stem cell in patients with acute myocardial infarction. Am J Cardiol 94(1):92-95

219. Cleland JG, Freemantle N, Coletta AP, Clark AL (2006) Clinical trials update from the American heart association: Repair-Ami, Astami, Jelis, Mega, Revive-II, Survive, and Proactive. Eur J Heart Fail 8(1):105-110

220. Marelli D, Desrosiers C, el-Alfy M, Kao RL, Chiu RC (1992) Cell transplantation for myocardial repair: an experimental approach. Cell Transpl 1(6):383-390

221. Taylor DA, Atkins BZ, Hungspreugs P, Jones TR, Reedy MC, Hutcheson KA, Glower DD, Kraus WE (1998) Regenerating functional myocardium: improved performance after skeletal myoblast transplantation. Nat Med 4(8):929-933

222. Hutcheson KA, Atkins BZ, Hueman MT, Hopkins MB, Glower DD, Taylor DA (2000) Comparison of benefits on myocardial performance of cellular cardiomyoplasty with skeletal myoblasts and fibroblasts. Cell Transpl 9(3): 359-368

223. Fujii T, Yau TM, Weisel RD, Ohno N, Mickle DA, Shiono N, Ozawa T, Matsubayashi K, Li RK (2003) Cell transplantation to prevent heart failure: a comparison of cell types. Ann Thorac Surg 76(6):2062-2070 (discussion 2070)

224. Schwarz ER, Speakman MT, Patterson M, Hale SS, Isner JM, Kedes LH, Kloner RA (2000) Evaluation of the effects of intramyocardial injection of DNA expressing vascular endothelial growth factor (VEGF) in a myocardial infarction model in the rat-angiogenesis and angioma formation. J Am Coll Cardiol 35(5):1323-1330

225. Kang HJ, Kim HS, Zhang SY, Park KW, Cho HJ, Koo BK, Kim YJ, Soo Lee D, Sohn DW, Han KS, Oh BH, Lee MM, Park YB (2004) Effects of intracoronary infusion of peripheral blood stem-cells mobilised with granulocytecolony stimulating factor on left ventricular systolic function and restenosis after coronary stenting in myocardial infarction: the MAGIC cell randomised clinical trial. Lancet 363(9411):751-756

226. Menasche P (2004) Embryonic stem cells pace the heart. Nat Biotechnol 22(10):1237-1238 